\title{
Gneiss-forming events in the Saglek Block, Labrador; a reappraisal of the Uivak gneiss
}

\author{
Anna Sałacińska ${ }^{1}$ - Monika A. Kusiak ${ }^{1} \cdot$ Martin J. Whitehouse ${ }^{2} \cdot$ Daniel J. Dunkley $^{3} \cdot$ Simon A. Wilde $^{4}$. \\ Ross Kielman ${ }^{2} \cdot$ Piotr Król $^{1}$
}

Received: 9 August 2018 / Accepted: 20 January 2019 / Published online: 18 February 2019

(c) The Author(s) 2019

\begin{abstract}
The Archean gneiss complex of the Saglek Block of Labrador is a part of the North Atlantic Craton, and is correlated with southern West Greenland, both being metamorphosed during a ca. $2.7 \mathrm{Ga}$ event. The main component of the complex is the Eoarchean Uivak orthogneiss, which includes lenses of the Nulliak supracrustal assemblage. Both lithologies are cut by the mafic Saglek metadykes. The Uivak gneisses have been divided into Uivak I grey gneiss and Uivak II augen gneiss. The former underwent ca. 3.6 Ga high-T metamorphism prior to the intrusion of the latter. However, the exact age, nature, and extent of Uivak II gneiss are poorly understood. We present geochemical and geochronological results for both these orthogneisses to help refine the various hypotheses that have been proposed concerning the nature of their protoliths. Magmatic ages of $3746 \pm 5$ and $3717 \pm 6 \mathrm{Ma}$ are consistent with previous estimates for the age of Uivak I gneiss. Uivak II augen gneiss from Maidmonts Island, where there is a clear intrusive relationship between the Uivak II and Uivak I gneissic protoliths, has an age of $3325 \pm 3 \mathrm{Ma}$. This is similar to an homogeneous grey gneiss from St. John's Harbour, with an age of $3318 \pm 5 \mathrm{Ma}$. Grey gneiss from Big Island is distinctively younger (3219 $\pm 7 \mathrm{Ma})$, and equivalent to the ca. $3.24 \mathrm{Ga}$ Lister gneiss. Our study shows that granitic gneisses classified as Uivak II were emplaced 200-300 million years after ca. 3.6 Ga metamorphism and deformation of the Uivak I gneiss. The igneous protolith of Uivak II gneiss pre-dates the Lister gneiss by about $100 \mathrm{Ma}$. The Uivak I and Lister gneisses are geochemically similar, and are both Tonalite-Trondhjemite-Granodiorite (TTG) gneisses, whereas the Uivak II gneiss is a granitoid partially derived from pre-existing crust. We propose abandoning the term 'Uivak II gneiss', and renaming ca. 3.3 Ga granitoids, after the type locality, as Maidmonts gneiss. This restricts the term 'Uivak gneiss' to Eoarchean TTG gneisses and removes the necessity for subdividing them into Uivak I and II.
\end{abstract}

Keywords Saglek block $\cdot \mathrm{U}-\mathrm{Pb}$ geochronology $\cdot$ Uivak gneiss $\cdot$ TTG gneiss

\section{Introduction}

The Archean Nain Province is located along the eastern coast of Labrador (Canada), and forms the western margin of the North Atlantic Craton. The province has been

Anna Sałacińska

anna.salacinska@twarda.pan.pl

1 Institute of Geological Sciences, Polish Academy of Sciences, Twarda 51/55 St., 00818 Warsaw, Poland

2 Swedish Museum of Natural History, SE104 05 Stockholm, Sweden

3 Faculty of Earth Sciences, University of Silesia in Katowice, 41205 Sosnowiec, Poland

4 School of Earth and Planetary Sciences, Curtin University, PO Box U1987, Perth WA 6845, Australia correlated with Archean terranes in southern West Greenland (Bridgwater et al. 1973; Nutman et al. 2004a; Hölttä et al. 2008) across the Labrador Sea. To the west and south, the Nain Province is bordered by early-to-mid-Proterozoic orogenic belts named the Churchill, Grenville, and Makkovik provinces (Taylor 1971; Greene 1974). The Nain Province is divided into two Archean blocks, the northern Saglek Block, and the southern Hopedale Block (Fig. 1), which are separated by the mid-Proterozoic Nain Plutonic Suite (Bridgwater and Schiøtte 1991; Wasteneys et al. 1996). The Saglek Block is mainly composed of early Archean Uivak TTG gneisses, with subordinate belts of mafic and metasedimentary supracrustal rocks that include the so-called 'Nulliak assemblage'. Comparable lithologies are found across the Labrador Sea in South West Greenland, where the early Archean Itsaq Gneiss Complex (IGC) (Nutman 
Fig. 1 Geological map of northeast Labrador from Ramah Bay to Hebron Fjord, modified after Wardle et al. (1997). Sample locations for this and previous studies are represented by symbols: 1 -Schiøtte et al. (1989a); 2-Vezinet et al. (2018); 3-Krogh and Kamo (2006); 4-Komiya et al. (2017); 5-Shimojo et al. (2016); 6-Sałacińska et al. (2018); 7-Kusiak et al. (2018); 8-Dunkley et al. (submitted); 9-Wasteneys et al. (1996). Inset (top): Inferred boundaries of the North Atlantic Craton (NAC) in Labrador and southern Greenland. Inset (bottom): the geological provinces of Labrador

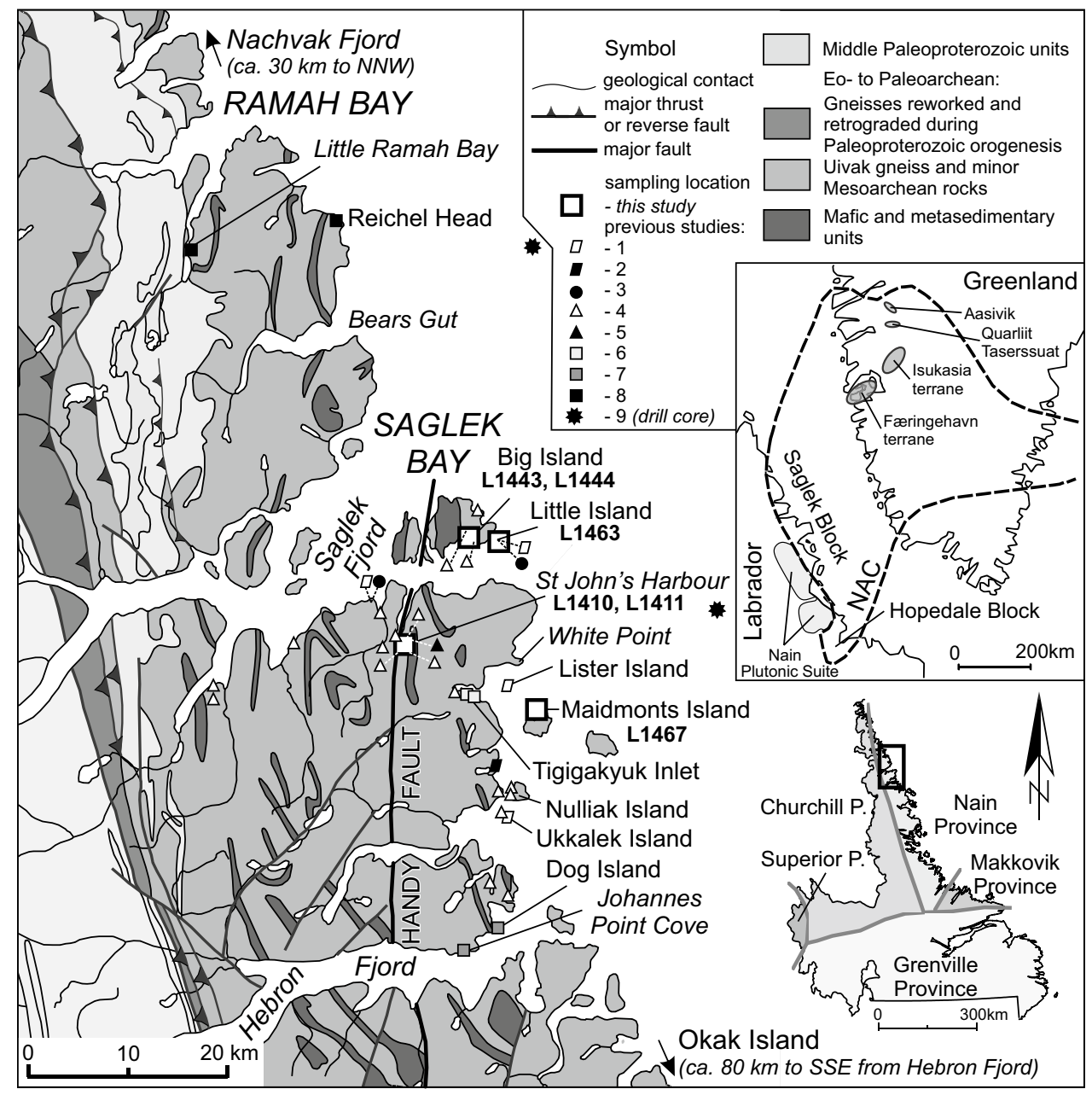

et al. 1996) contains the Amîtsoq TTG gneisses (McGregor 1973) associated with the metasupracrustal Akilia Association (McGregor and Mason 1977), which includes the Isua Greenstone Belt (Fedo et al. 2001). The Itsaq Gneiss Complex contains the most extensive and well-studied early Archean rock record (Nutman et al. 1996, 2004a), including some of the oldest identified rocks on Earth. The area comprises several generations of granitoid intrusions, emplaced between ca. 3.9 and 3.5 Ga (e.g., Nutman et al. 1996, 2000, 2004a, 2007, 2013; Whitehouse et al. 1999; Crowley 2003; Whitehouse and Kamber 2005; Næraa et al. 2012), which formed the protoliths of a major part of the Itsaq Gneiss Complex, together with younger orthogneisses and migmatites that were emplaced between ca. 3.2 and 2.8 Ga (Polat et al. 2010; Næraa et al. 2012). Most of these rocks acquired their structural elements and fabrics during Neoarchean tectonothermal events (around 2.8-2.7 Ga) (McGregor 1973; Chadwick and Nutman 1979; Whitehouse and Kamber 2005) with local low-strain domains that preserve evidence of ca. 3.6 Ga high-T metamorphism (e.g., Griffin et al. 1980; Nutman et al. 1996, 2002, 2013; Crowley 2003; Friend and Nutman 2005; Whitehouse and Kamber 2005).
In contrast, the Saglek Block in Labrador has not been so extensively studied. Early mapping (Bridgwater et al. 1975; Hurst et al. 1975; Bridgwater and Collerson 1976, 1977) followed by geochronological studies (Collerson and Bridgwater 1979; Shiotte et al. 1989a, b; Bridgwater and Schiøtte 1991) defined and dated major lithologies. More recently, a resurgence of interest in the Saglek Block has led to several detailed studies (Krogh and Kamo 2006; Shimojo et al. 2016; Komiya et al. 2017; Kusiak et al. 2018; Sałacińska et al. 2018) that revised earlier interpretations and produced new controversies (e.g. Tashiro et al. 2017; Whitehouse et al. 2019), especially regarding the oldest components of the block. Following the study of Sałacińska et al. (2018) that advanced understanding of the age and composition of the Uivak I gneiss, this study focuses on orthogneisses previously identified as the younger, but poorly understood, Uivak II gneiss. We present geochemical and geochronological results that test various hypotheses concerning the formation of early-tomid-Archean gneissic protoliths. We provide improved geochronological and geochemical characterisation of rocks formerly assigned to the Uivak II gneiss, and suggest 
a new definition for the gneisses that were produced much later than the predominant Uivak I gneiss.

\section{Geological setting}

The Saglek Block is located in the central part of the Archean Nain Province, and is separated by the Nain Plutonic Suite from the Hopedale Block in the south, whereas the northern boundary with the Nachvak Block is not clearly delineated owing to the lack of detailed mapping. The Saglek Block is well-exposed along the coast northwards from the Nain Plutonic Suite, between Okak Island and Nachvak Fjord (Fig. 1; Bridgwater and Schiøtte 1991; Wasteneys et al. 1996). The block is subdivided at Saglek Bay into two segments by the major N-S trending Handy Fault, which separates rocks of different crustal levels. The western part of the Saglek Block consists of granulite-facies rocks, whereas the eastern part reveals a transition from amphibolite facies in the north (from Big Island through Tigigakyuk Inlet to Lister Island; Fig. 1) to granulite facies southward to Hebron Fjord (Bridgwater et al. 1975; Schiøtte et al. 1989a). The Saglek Block contains a strongly deformed Archean gneiss complex, consisting predominantly of quartzo-feldspathic gneisses of igneous origin, which are tectonically juxtaposed and interleaved with supracrustal rocks. The major component of the complex is the early Archean Uivak orthogneiss, which has been subdivided into the older Uivak I tonalite-trondhjemite-granodiorite (TTG) gneisses and younger Uivak II gneisses. Macro-scale tectonic lenses of the Nulliak supracrustal assemblage are intercalated with the Uivak gneisses, and both are cut by metamorphosed plagioclase-phyric mafic Saglek dykes (Bridgwater et al. 1975; Bridgwater and Collerson 1976, 1977). These units have been correlated with the Itsaq Gneiss Complex in southern West Greenland (Sałacińska et al. 2018 and references therein), which is intruded by the plagioclase-phyric Ameralik dyke swarm (Nutman et al. 2004b), a likely Saglek dyke correlative. The oldest recognized post-Saglek dyke orthogneiss from the Saglek Block is the felsic Paleoarchean Lister gneiss (Schiøtte et al. 1989a). Contacts between the older Uivak and younger Lister gneisses are tectonic, and no evidence for intrusive relationships has been recognized (Bridgwater and Schiøtte 1991). The Upernavik supracrustal assemblage is a composite group of rocks of several ages, which is more extensively exposed than the older Nulliak assemblage. The Upernavik supracrustal assemblage is dominated by pelitic and psammitic units. The original distinction between the older Nulliak and younger Upernavik assemblages was based on the absence of Saglek dykes within the younger rocks (Bridgwater et al. 1975; Bridgwater and Collerson 1976, 1977; Schiøtte et al. 1989a, b). Further investigation showed that some "Upernavik-like" lithologies are cut by mafic dykes assigned to the Saglek swarm (Bridgwater and Schiøtte 1991). Therefore, lithological differences, such as the presence of banded ironstones and metacherts only in the Nulliak assemblage, are considered more appropriate in distinguishing these two units (Bridgwater and Collerson 1976, 1977; Ryan and Martineau 2012). The present outcrop pattern is a result of tectonic intercalation and subsequent folding of orthogneisses and supracrustal rocks during a late Archean metamorphic event at ca. 2.8-2.7 Ga and/ or ca. $2.5 \mathrm{Ga}$ reaching granulite-facies conditions (Krogh and Kamo 2006; Connelly and Ryan 1996; Bridgwater and Schiøtte 1991; Schiøtte et al. 1989a, b).

\section{Definition and characteristics of 'Uivak gneiss' in relation to other gneisses in the area}

The original definition of the Uivak gneiss was given by Bridgwater et al. (1975): "The Uivak gneisses are a composite group of quartzo-feldspathic rocks which may not all belong to the same igneous suite. They are described as a single lithological unit because of their relation with [intrusion by] the Saglek dykes". The Uivak gneisses consist of felsic grey gneisses (Uivak I gneiss), along with porphyritic granitoid gneisses and a range of calc-alkaline intrusions (Uivak II gneiss; Bridgwater and Collerson 1976). The Uivak I gneisses are grey, compositionally varied, fine- to medium-grained, quartzo-feldspathic and partially migmatized. Homogeneous parts of the gneiss are dominated by TTG compositions (Collerson and Bridgwater 1979). More mafic phases, including gabbroic, dioritic and monzonitic gneisses, are locally present. Field observations in areas of relatively low finite strain show that the Uivak I gneiss was affected by at least one major period of deformation and migmatization prior to the intrusion of the Uivak II gneissic protolith (Bridgwater et al. 1975; Bridgwater and Collerson 1976; Collerson and Bridgwater 1979).

The less extensive Uivak II gneiss occurs in a relatively narrow, localised belt, parallel to gneissosity, extending SSE from the southern coast of Big Island, through White Point, Mentzel Island, and Maidmonts Island, to the coast opposite Nulliak Island (Fig. 1). Originally, the Uivak II gneiss was defined as a co-genetic suite of plutonic bodies that include iron-rich porphyritic granodiorites and ferrodiorites intruded into deformed and migmatized Uivak I gneiss, although any original intrusive relationships were largely obscured by subsequent strong deformation (Bridgwater et al. 1975; Hurst et al. 1975; Bridgwater and Collerson 1976; Collerson and Bridgwater 1979). Four main components of the Uivak II gneiss were identified: (a) coarse-grained granitic gneiss with large feldspar augen; (b) hornblende-rich ferrodiorites; (c) feldspar-phyric biotite-rich inhomogeneous 
quartz monzonite sheets; and (d) thin hornblende-rich dykes (Bridgwater et al. 1975; Bridgwater and Collerson 1976). The last three types were identified from the southern part of Big Island. A Rb-Sr whole-rock errorchron of ca. $3.6 \mathrm{Ga}$, derived from a combination of Uivak I and II samples led Bridgwater and Collerson (1976) to suggest that both types were broadly contemporaneous. However, further detailed geochronology (Baadsgaard et al. 1979) showed that the iron-rich suite from Big Island was a comparatively late (ca. 2.8-2.5 Ga) minor association, and it was, thereafter excluded from the Uivak II gneiss. Subsequently, the assumption that Uivak II protoliths formed at ca. 3.6 Ga has never been tested.

The first evidence of an early Archean age for the Uivak I gneiss was provided by whole-rock $\mathrm{Rb}-\mathrm{Sr}$ isotopic dating ( $3545 \pm 72 \mathrm{Ma}$; Hurst et al. 1975; and 3533 + 315/-238 Ma; Collerson et al. 1982) and this was confirmed by multigrain $\mathrm{U}-\mathrm{Pb}$ zircon dating using isotope dilution-thermal ionisation mass spectrometry (ID-TIMS) (> $3485 \mathrm{Ma}$; Baadsgaard et al. 1979). The first precise age of the formation of Uivak I gneiss ( $3732 \pm 6 \mathrm{Ma})$ was determined on zircon by Secondary Ion Mass Spectrometry (SIMS) by Schiøtte et al. (1989a). Further high-precision SIMS zircon ages were provided by Kusiak et al. (2018), Sałacińska et al. (2018) and Vezinet et al. (2018). Vezinet et al. (2018) have identified a felsic gneiss with a protolith age of $3.86 \pm 0.01 \mathrm{Ga}$. Isotopic $\mathrm{U}-\mathrm{Pb}$ dating of zircon grains also identified a significant amount of older zircon, up to ca. $3.92 \mathrm{Ga}$ in age (Collerson 1983; Schiøtte et al. 1989a; Shimojo et al. 2016). However, it has not been clearly demonstrated whether such zircon grew in the magmatic protolith or if it was inherited from the source rocks. A re-interpretation of the age of the Uivak I gneiss was presented by Krogh and Kamo (2006), who, on the basis of new zircon dating of grey gneisses in Saglek Bay, suggested that they include two unrelated generations of magmatism, the first at $3634 \pm 31 \mathrm{Ma}$ (with inheritance back to $3730 \mathrm{Ma}$ ), and the second at $3348 \pm 7 \mathrm{Ma}$, located on the west and east sides of the Handy Fault, respectively. Further re-investigation of grey gneisses mapped as Uivak gneiss by laser ablation-inductively coupled plasma-mass spectrometry (LA-ICP-MS) U-Pb dating of zircon was conducted by Komiya et al. (2017). Their results led them to propose a new model of 'prolonged' granitoid formation with gneisses grouped into five age ranges (Uivak A-E) of approximately 50 my each over a 300 million-year period between 3.9 and 3.6 Ga. Previous attempts at $\mathrm{U}-\mathrm{Pb}$ zircon dating of Uivak II gneiss have not provided clear results. Wanless et al. (1979) calculated an upper intercept age of $3760 \pm 150 \mathrm{Ma}$, whereas a few discordant zircon analyses by Collerson (1983) recorded ${ }^{207} \mathrm{~Pb} /{ }^{206} \mathrm{~Pb}$ ages of ca. $3350 \mathrm{Ma}$.

The Lister gneiss, identified as a subvertical sheet of felsic orthogneisses amongst amphibolite-facies gneisses, is significantly younger (ca. 3.24 Ga) than Uivak I gneiss and post-dates the Saglek dykes (Schiøtte et al. 1989a). The type locality on Lister Island (Schiøtte et al. 1989a) yielded an age of $3235 \pm 8 \mathrm{Ma}$, with samples from other localities being slightly younger at $3219 \pm 3 \mathrm{Ma}$ and $3213 \pm 4 \mathrm{Ma}$ (Schiøtte et al. 1990; Wasteneys et al. 1996, respectively). Similar felsic gneisses, also ca. $3.2 \mathrm{Ga}$ in age, were subsequently identified from the south side of Saglek Bay (Bridgwater and Schiøtte 1991), on Big Island (Krogh and Kamo 2006), on Nulliak Island (Komiya et al. 2017), on Parkavik Island (Schiøtte et al. 1990) and offshore of the Saglek Block (drill core; Wasteneys et al. 1996), which indicated that ca. $3.24 \mathrm{Ga}$ gneisses are volumetrically more widespread than originally thought.

\section{Sample locations}

Sampling for this study was conducted between Saglek Bay and Hebron Fjord (Fig. 1). Rock types were chosen that were representative of both grey gneisses (typical of Uivak I) and augen gneisses (typical of Uivak II). A total of six samples were collected: from St. John's Harbour (L1410, L1411), Big Island (L1443, L1444), Little Island (L1463) and Maidmonts Island (L1467) (Fig. 1). Samples from St. John's Harbour represent homogeneous fine-grained gneiss (L1410) and banded grey gneiss (L1411), with gneissic layers of slightly differing composition. From field observations, the latter sample (L1411) contains more than one igneous protolith intercalated through ductile deformation. The samples from Big Island represent weakly porphyroblastic (L1443) and homogeneous (L1444) fine-grained grey gneisses and were collected from the coast between localities previously sampled by Komiya et al. $(2015,2017)$, who obtained ca. $3.22 \mathrm{Ga}$ and ca. $3.73 \mathrm{Ga}$ ages. An intrusive relationship between these two grey gneisses was not identified and none of the sampled outcrops are cut by mafic dykes or pegmatite (Fig. 2c, d). On Little Island, an homogeneous fine-grained grey gneiss (L1463) was sampled from an outcrop containing grey gneiss with dismembered fragments of mafic dykes and pegmatite (Fig. 2e). A similar outcrop was found by Krogh and Kamo (2006), who determined the age of the orthogneiss at ca. $3.35 \mathrm{Ga}$, cut by a mafic dyke at ca. $2.70 \mathrm{Ga}$ and by pegmatite at ca. $2.56 \mathrm{Ga}$. However, orthogneiss L1463 from our sample locality is different from the orthogneiss dated by Krogh and Kamo (2006), because it is interleaved with coarsegrained pegmatite veins $1-2 \mathrm{~cm}$ wide. Porphyroclastic gneiss (L1467; Fig. 2f) was collected from Maidmonts Island, where the largest body of Uivak II gneiss occurs, and it extends at least $3 \mathrm{~km}$ along strike (Fig. 3; Bridgwater and Collerson 1976). At this locality, a deformed and transposed contact between augen gneiss (L1467), 

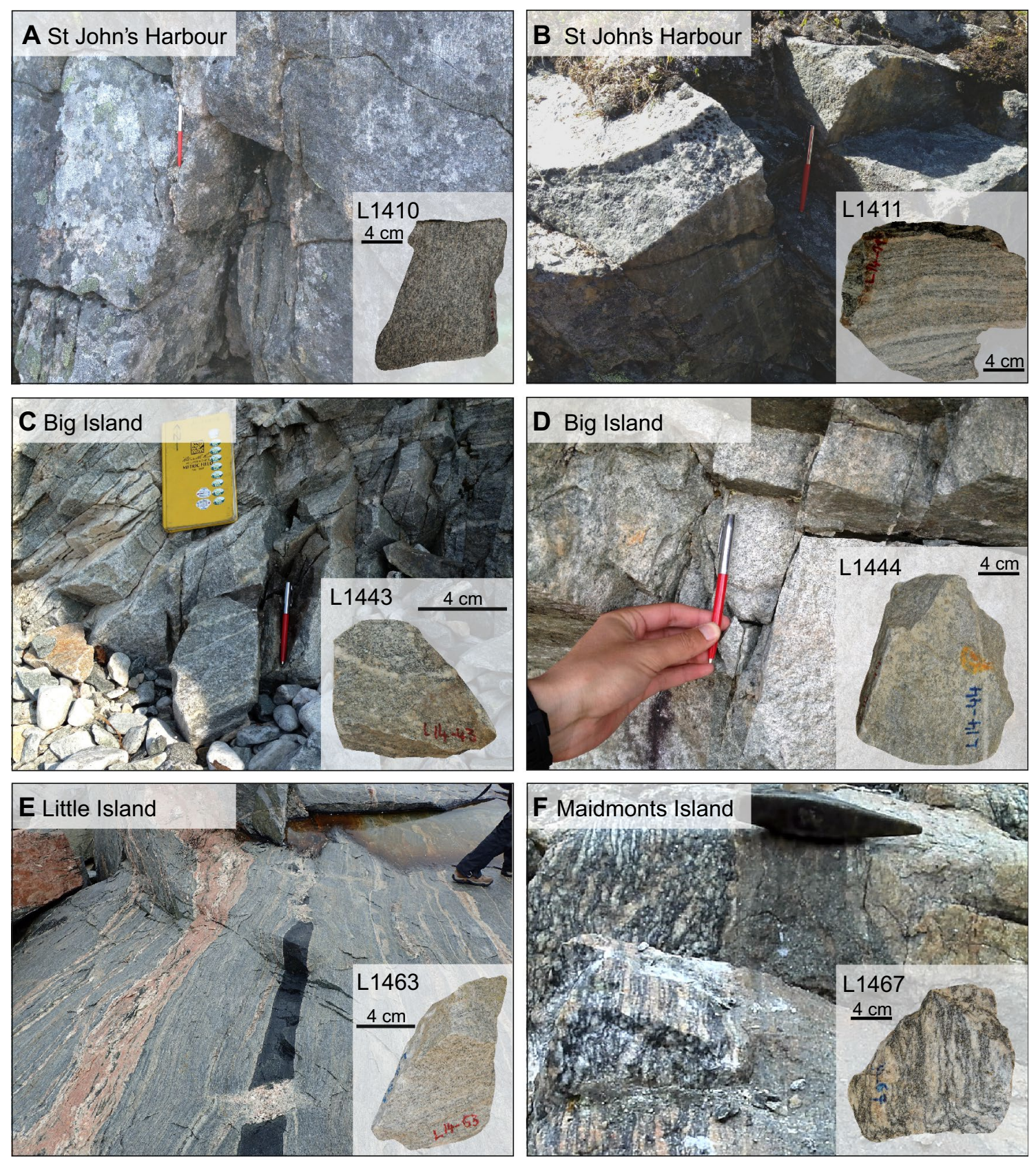

Fig. 2 Sample localities of gneisses in the Saglek Block: a homogeneous fine-grained gneiss L1410 from St. John's Harbour; b banded grey gneiss L1411 from St. John's Harbour; c weakly pophyroblastic gneiss L1443 from Big Island; d homogeneous fine-grained gneiss L1444 from Big Island; e grey gneiss (L1463) from Little Island,

grey gneiss and syn-tectonic white granitoid, was identified (Fig. 2f). In another outcrop on the island, we noted a clear intrusive relationship between the younger Uivak II and older Uivak I gneisses (Fig. 3).

All six samples, including homogeneous (L1410, L1444 and L1463), weakly porphyroblastic (L1443), and banded (L1411) fine-grained grey gneisses and porphyroclastic cut by dismembered mafic dyke and intruded by syn-tectonic granite, which is deformed into a late gneissosity that transposes the earlier gneissosity on Little Island; $\mathbf{f}$ deformed and transposed contacts between porphyroclastic gneiss (L1467), grey gneiss and granitoid on Maidmonts Island

gneiss (L1467), have granoblastic textures. Sample locations, rock types as classified by whole-rock geochemistry, and mineral assemblages are listed in Table 1. 

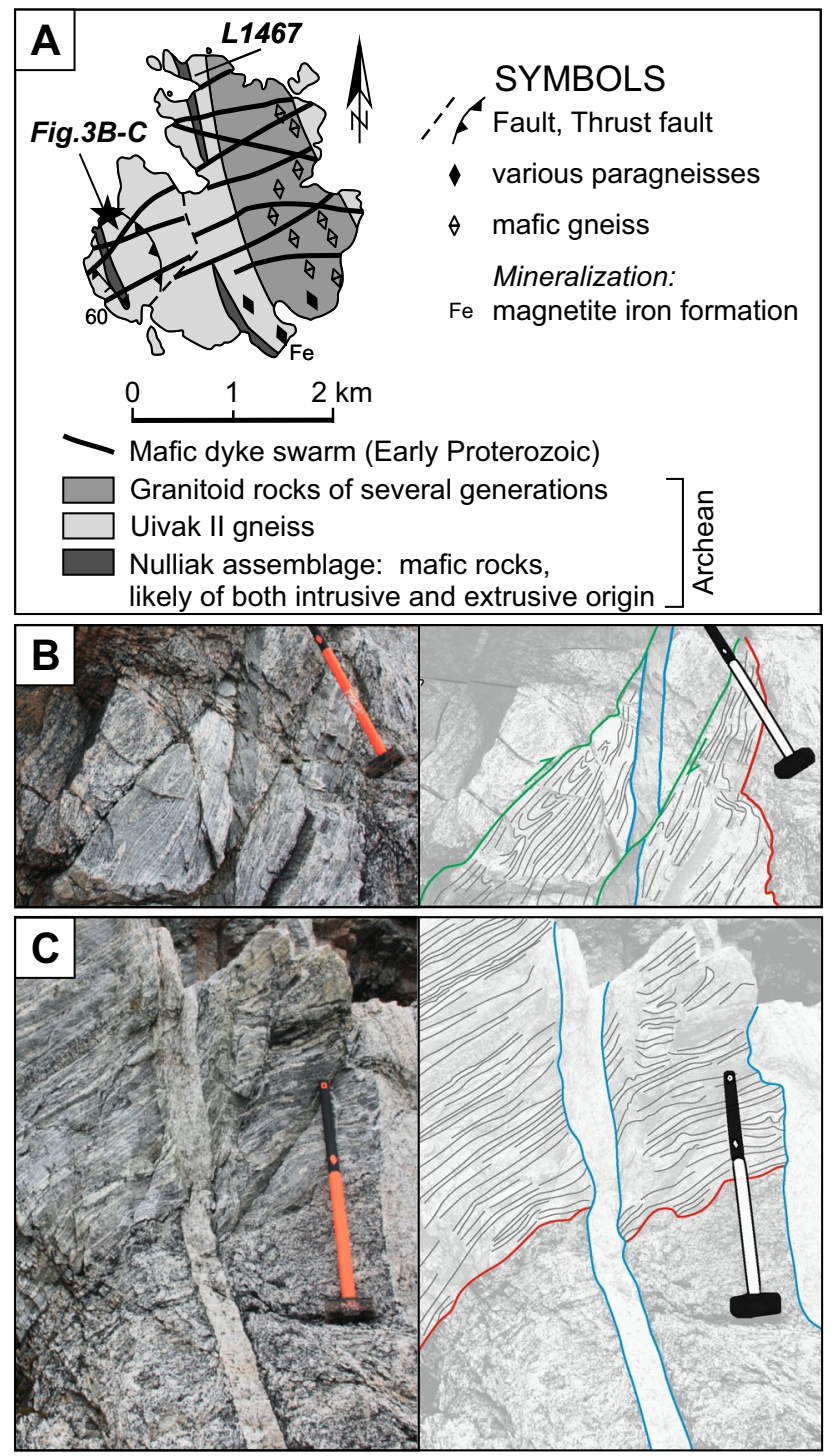

Fig. 3 a Geological map of Maidmonts Island showing sample location modified after Ryan and Martineau (2012). b Location of porphyroclastic gneiss, whose protolith intrudes earlier gneissosity in strongly laminated pale grey gneiss on Maidmonts Island. All gneisses are cut by K-feldspar-rich pegmatite and granodioritic dykes. c Intrusive relationship between originally porphyritic granite and fine-grained grey gneiss on the west coast of Maidmonts Island. Porphyroclastic gneiss protolith intruded strongly laminated pale grey gneiss. Green line-fault; red line-intrusive contact between socalled Uivak I and Uivak II gneisses; blue line-granitic to granodioritic dykes intruded along faults

\section{Analytical procedures}

For geochemical analyses, the most uniform parts of the samples were selected and all weathered material was removed. They were then crushed and milled in an agate ball mill. The material was then coned and quartered before being despatched for analysis of major and trace elements at the Bureau Veritas Analytical Laboratories in Vancouver,
Canada. X-ray fluorescence (XRF) spectrometry was used for major elements, whereas inductively coupled plasma mass spectrometry (ICP-MS) was used for trace elements, including REE. The volatile content of each sample was determined by loss on ignition (LOI). The data were then plotted in diagrams using the GeoChemical Data toolkit (GCDkit) (Janoušek et al. 2016).

Separation of zircon was conducted at the Sample Separation Laboratory, Institute of Geological Sciences PAS (Krakow). Crushed material was run through Carpco and Frantz magnetic separators to remove magnetic minerals. To isolate heavy minerals, tetrabromoethane (TBE) was used. Zircon was then separated from other heavy minerals by hand-picking under a binocular microscope. The zircons were then placed together with the reference material (zircon 91500, Wiedenbeck et al. 1995) in epoxy resin mounts and then polished to expose the centre of the grains. All zircon grains were imaged and documented in transmitted and reflected light and by scanning electron microscopy. For scanning electron microscopy, the grains were carbon coated prior to being imaged using cathodoluminescence (CL) to highlight the internal structure of the crystals. Before analyses, the epoxy mounts were cleaned in an ultrasonic bath and gold coated for $\mathrm{U}-\mathrm{Th}-\mathrm{Pb}$ isotopic analysis.

$\mathrm{U}-\mathrm{Th}-\mathrm{Pb}$ isotopic analysis of zircon was undertaken at the Department of Geosciences in the Swedish Natural History Museum (Stockholm, Sweden), using a CAMECA IMS 1280 secondary ion mass spectrometer (SIMS) in the NordSIM analytical facility: the analytical method was according to Whitehouse and Kamber (2005). The analytical conditions during analysis consisted of using a nominal $\sim 20 \mu \mathrm{m}$, $6 \mathrm{nA} \mathrm{O}^{2-}$ ion beam in dynamic mono-collection mode and an ion counting electron multiplier (EM) ion counter at a mass resolution of $\sim 5400(M / \Delta M)$. The protocol of Jeon and Whitehouse (2015) was used for calibrating the $\mathrm{Pb} / \mathrm{U}$ ratios using the $\mathrm{Pb} / \mathrm{UO}$ vs. $\mathrm{UO}_{2} / \mathrm{UO}$ method based on zircon standard 91500 . The 91500 zircon has a $\mathrm{U}$ concentration of $80 \mathrm{ppm}$ and an age of $1065 \mathrm{Ma}$ (Wiedenbeck et al. 1995). Common $\mathrm{Pb}$ was corrected using the ${ }^{204} \mathrm{~Pb}$ counts, where these exceeded $3 \times$ the standard deviation on the average background. Common $\mathrm{Pb}$ composition assumes the presentday terrestrial $\mathrm{Pb}$-isotope composition model (Stacey and Kramers 1975), following the rationale of Zeck and Whitehouse (1999) that this is largely surface contamination introduced during sample preparation and not common $\mathrm{Pb}$ residing in zircon and/or micro-inclusions. During spot analyses, very low concentrations of common $\mathrm{Pb}\left(f^{206} \mathrm{~Pb}<0.1 \%\right)$ were detected and have little influence on the ages. The in-house software developed by M.J. Whitehouse was used for data reduction, and the ages were calculated using Isoplot $\mathrm{v} 4.15$ (Ludwig 2012). In the tables, the data are quoted with $1 \sigma$ analytical errors, whereas weighted mean calculations and discordia intercept ages are quoted at $95 \%(2 \sigma)$ confidence 
Table 1 Sample locations and modal mineral assemblages

\begin{tabular}{|c|c|c|c|c|c|c|c|c|c|c|c|c|c|c|c|}
\hline Sample & Type & Locality & Latitude & Longitude & Qz & $\mathrm{Pl}$ & Afs & $\mathrm{Hbl}$ & $\mathrm{Bt}$ & Py & Chl & Ser & Ep & Zrn & Ap \\
\hline L1410 & Granitic orthogneiss & St John's Harbour & $58^{\circ} 26.76^{\prime} \mathrm{N}$ & $62^{\circ} 47.53^{\prime} \mathrm{W}$ & $\bullet \bullet \bullet$ & $\bullet \bullet \bullet$ & $\bullet \bullet$ & & $\bullet \bullet$ & & $2^{\circ}$ & $2^{\circ}$ & $2^{\circ}$ & $\bullet$ & $\bullet$ \\
\hline L1411 & Granitic orthogneiss & St John's Harbour & $58^{\circ} 26.76^{\prime} \mathrm{N}$ & $62^{\circ} 47.43^{\prime} \mathrm{W}$ & $\bullet \bullet \bullet$ & $\bullet \bullet \bullet$ & $\bullet \bullet$ & & $\bullet \bullet$ & & $2^{\circ}$ & $2^{\circ}$ & & $\bullet$ & $\bullet$ \\
\hline L1443 & Trondhjemitic orthogneiss & Big Island & $58^{\circ} 32.55^{\prime} \mathrm{N}$ & $62^{\circ} 40.60^{\prime} \mathrm{W}$ & $\bullet \bullet \bullet$ & $\bullet \bullet \bullet$ & $\bullet \bullet$ & & $\bullet \bullet$ & & $2^{\circ}$ & $2^{\circ}$ & & $\bullet$ & $\bullet$ \\
\hline L1444 & Trondhjemitic orthogneiss & Big Island & $58^{\circ} 32.79^{\prime} \mathrm{N}$ & $62^{\circ} 41.07^{\prime} \mathrm{W}$ & $\bullet \bullet \bullet$ & $\bullet \bullet \bullet$ & $\bullet \bullet$ & $\bullet \bullet$ & $\bullet \bullet$ & & $2^{\circ}$ & $2^{\circ}$ & & $\bullet$ & $\bullet$ \\
\hline L1463 & Trondhjemitic orthogneiss & Little Island & $58^{\circ} 32.06^{\prime} \mathrm{N}$ & $62^{\circ} 38.64^{\prime} \mathrm{W}$ & $\bullet \bullet \bullet$ & $\bullet \bullet \bullet$ & $\bullet \bullet \bullet$ & & $\bullet \bullet$ & & $2^{\circ}$ & $2^{\circ}$ & $2^{\circ}$ & $\bullet$ & $\bullet$ \\
\hline L1467 & Granitic orthogneiss & Maidmonts Island & $58^{\circ} 23.28^{\prime} \mathrm{N}$ & $62^{\circ} 33.55^{\prime} \mathrm{W}$ & $\bullet \bullet \bullet$ & $\bullet \bullet \bullet$ & $\bullet \bullet$ & & $\bullet \bullet$ & & $2^{\circ}$ & $2^{\circ}$ & $2^{\circ}$ & $\bullet$ & $\bullet$ \\
\hline
\end{tabular}

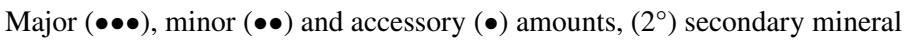

$Q z$ Quartz, $P l$ plagioclase, $A f s$ alkali feldspar, $H b l$ hornblende, $B t$ biotite, $P y$ pyrite, $C h l$ chlorite, $S e r$ sericite, $E p$ epidote, $Z r n$ zircon, $A p$ apatite

levels, and include the decay constant error. Data with common $\mathrm{Pb}$ content $>1 \% \mathrm{~Pb}$ were excluded from ${ }^{207} \mathrm{~Pb} /{ }^{206} \mathrm{~Pb}$ pooled age calculation, as were data with absolute discordance $>5 \%$.

\section{Results}

\section{Whole-rock geochemistry}

Whole-rock major and trace element compositions for gneisses from the Saglek Block are given in Table 2.

All samples are silica-rich (66.0-73.7 wt.\% $\left.\mathrm{SiO}_{2}\right)$ and have variable contents of aluminium (13.5-18.5 wt.\% $\mathrm{Al}_{2} \mathrm{O}_{3}$ ). The variable contents of sodium (3.6-5.7 wt.\% $\mathrm{Na}_{2} \mathrm{O}$ ) and potassium (1.4-4.1 wt. $\% \mathrm{Na}_{2} \mathrm{O}$ ) are reflected in the range of $\mathrm{K}_{2} \mathrm{O} / \mathrm{Na}_{2} \mathrm{O}$ ratios (0.25-1.09), with the highest ratios in fine-grained gneiss L1410 and porphyroclastic gneiss L1467. The gneisses also have variable contents of ferromagnesian oxides, ranging from 1.9 to $5.4 \mathrm{wt} . \%$ $\left(\mathrm{Fe}_{2} \mathrm{O}_{3} *+\mathrm{MgO}+\mathrm{MnO}+\mathrm{TiO}_{2}\right.$ wt. $\%, \mathrm{Fe}_{2} \mathrm{O}_{3}{ }^{*}=$ total $\mathrm{Fe}$ expressed as $\mathrm{Fe}_{2} \mathrm{O}_{3}$ ).

Samples plot in the granodiorite (L1443 and L1444) and granite (L1410, L1411, L1463 and L1467) fields in the TAS diagram (Middlemost 1994) and are close to the boundaries between granite, granodiorite and quartz monzonite (Fig. 4a). In the normative An-Ab-Or ternary diagram (Barker 1979; after O'Connor 1965), the samples plot in the trondhjemite (L1443, L1444 and L1463) and granite (L1410, L1411 and L1467) fields. This diagram is used for classification of our samples following Jahn et al. (1981) classification of Archean TTG gneisses. Samples L1463 and L1411 are close to the trondhjemite-granite boundary (Fig. 4b). All samples are weakly peraluminous (Fig. 4c). In the AFM diagram (Irvine and Baragar 1971), the samples follow the calc-alkaline trend (Fig. 4d), although two of them (L1410 and L1467) are located closer to the A-F side of the ternary diagram. In the $\mathrm{Nb} / \mathrm{Ta}$ diagram (Fig. 4e), all samples plot within the fields of high- and medium-pressure
TTG (Moyen 2011), similar to Archean gneisses from southern West Greenland.

The trace elements were normalized to the primitive mantle (PM) values from McDonough and Sun (1995) (Fig. 5a). Four samples, including banded grey gneiss L1411, weakly porphyroblastic gneiss L1443, fine-grained gneisses L1444 and L1463, have similar trace element profiles, with strongly negative $\mathrm{Nb}-\mathrm{Ta}$ and $\mathrm{P}$ anomalies, weak to moderate negative $\mathrm{Ti}$ anomalies and a minor peak in Sr. Sample L1410 is geochemically similar to sample L1467, with low $\mathrm{U}, \mathrm{Nb}, \mathrm{Ta}, \mathrm{Sr}$, $\mathrm{P}$, and weak negative Ti anomalies. These two samples have the highest contents of $\mathrm{Th}$ and $\mathrm{Zr}$. All samples are strongly enriched in $\mathrm{Rb}$ (94-174 ppm) and $\mathrm{Ba}$ (196-1232 ppm) relative to PM (Table 2).

The rare earth elements (REEs) were normalized to the chondrite values of McDonough and Sun (1995). The gneisses have relatively high light rare earth element contents (LREE) (11.0-99.1 ppm La) and low heavy rare earth element (HREE) contents $(0.22-0.39 \mathrm{ppm} \mathrm{Yb})$, with $\mathrm{La} / \mathrm{Yb}$ ratios ranging from 28 to 310 (Table 2; Fig. 5b). Two samples, fine-grained gneiss L1410 and porphyroclastic gneiss L1467, show the strongest fractionation of LREE/HREE $(\mathrm{La} / \mathrm{Yb}$ ratios of 3010 and 145 , respectively) and have distinct negative Eu anomalies, whereas the other four samples do not.

\section{$\mathrm{U}-\mathrm{Pb}$ geochronology}

The results are presented in order of sample collection. SIMS U-Th-Pb isotopic data are given in Tables 3, 4, 5, 6, 7 and 8 for samples L1410, L1411, L1443, L1444, L1463 and L1467, respectively.

Granitic gneiss sample L1410 from St. John's Harbour contains mostly subhedral to anhedral elongate zircons (up to $230 \mu \mathrm{m}$ in length, with a typical aspect ratio of 2:1). Most grains are zoned, with uniform to weakly zoned CLdark cores (Fig. 6a, grains 3, 8), whereas other grains have relatively CL-bright cores that grade into CL-dark rims (Fig. 6a, grain 4). Twenty-four analyses were undertaken on twenty-one grains from CL-dark and CL-bright cores 
Table 2 Whole-rock major and trace element compositions of gneisses from the Saglek Block

\begin{tabular}{|c|c|c|c|c|c|c|}
\hline Sample & L1410 & L1411 & L1443 & L1444 & L1463 & L1467 \\
\hline $\mathrm{SiO}_{2}$ & 70.8 & 73.7 & 66.5 & 66.0 & 72.3 & 71.2 \\
\hline $\mathrm{TiO}_{2}$ & 0.40 & 0.14 & 0.35 & 0.27 & 0.17 & 0.46 \\
\hline $\mathrm{Al}_{2} \mathrm{O}_{3}$ & 14.37 & 14.6 & 16.61 & 18.5 & 15.13 & 13.54 \\
\hline $\mathrm{Fe}_{2} \mathrm{O}_{3}$ & 3.09 & 1.28 & 3.33 & 2.48 & 1.31 & 4.31 \\
\hline $\mathrm{MnO}$ & 0.03 & 0.02 & 0.03 & 0.03 & 0.02 & 0.05 \\
\hline $\mathrm{MgO}$ & 0.67 & 0.45 & 1.17 & 1.19 & 0.37 & 0.61 \\
\hline $\mathrm{CaO}$ & 1.76 & 1.51 & 2.49 & 3.49 & 1.79 & 1.60 \\
\hline $\mathrm{Na}_{2} \mathrm{O}$ & 3.79 & 4.53 & 5.17 & 5.66 & 4.65 & 3.62 \\
\hline $\mathrm{K}_{2} \mathrm{O}$ & 4.13 & 3.56 & 1.87 & 1.43 & 3.17 & 3.77 \\
\hline $\mathrm{P}_{2} \mathrm{O}_{5}$ & 0.13 & 0.05 & 0.09 & 0.07 & 0.02 & 0.10 \\
\hline LOI & 0.60 & 0.26 & 2.20 & 1.21 & 1.00 & 0.60 \\
\hline Cs & 1.7 & 2.6 & 2.6 & 1.1 & 1.1 & 2.0 \\
\hline $\mathrm{Rb}$ & 157 & 144 & 112 & 94 & 106 & 174 \\
\hline $\mathrm{Ba}$ & 1232 & 451 & 196 & 204 & 321 & 372 \\
\hline $\mathrm{Nb}$ & 5.5 & 4.1 & 6.0 & 2.4 & 2.9 & 8.9 \\
\hline $\mathrm{Ta}$ & 0.2 & 0.3 & 0.3 & 0.2 & 0.2 & 0.4 \\
\hline $\mathrm{Sr}$ & 244 & 269 & 316 & 362 & 392 & 106 \\
\hline $\mathrm{Zr}$ & 290 & 110 & 129 & 108 & 108 & 238 \\
\hline Y & 4.8 & 5.7 & 5.7 & 4.6 & 3.8 & 5.2 \\
\hline $\mathrm{Hf}$ & 7.2 & 3.3 & 3.5 & 2.6 & 3.6 & 6.3 \\
\hline $\mathrm{Ni}$ & $<20$ & 1.4 & $<20$ & 9.2 & $<20$ & $<20$ \\
\hline V & 22 & 18 & 37 & 37 & 17 & 30 \\
\hline $\mathrm{Pb}$ & n.a. & 5.1 & n.a. & 8.3 & n.a. & n.a. \\
\hline $\mathrm{U}$ & 0.1 & 0.6 & 0.5 & 0.4 & 0.5 & 0.1 \\
\hline Th & 19.3 & 5.3 & 6.2 & 2.1 & 6.3 & 10.5 \\
\hline $\mathrm{La}$ & 99.10 & 17.70 & 30.50 & 11.00 & 19.90 & 50.70 \\
\hline $\mathrm{Ce}$ & 159.4 & 32.7 & 58.2 & 18.9 & 43.7 & 84.5 \\
\hline $\operatorname{Pr}$ & 17.46 & 3.35 & 5.97 & 2.17 & 4.69 & 11.18 \\
\hline $\mathrm{Nd}$ & 52 & 11.3 & 21.1 & 8.4 & 18.1 & 40.1 \\
\hline $\mathrm{Sm}$ & 5.82 & 1.99 & 3.18 & 1.69 & 3.19 & 4.96 \\
\hline $\mathrm{Eu}$ & 0.74 & 0.49 & 0.57 & 0.58 & 0.78 & 0.53 \\
\hline $\mathrm{Gd}$ & 4.07 & 1.7 & 2.41 & 1.43 & 2.02 & 3.55 \\
\hline $\mathrm{Tb}$ & 0.30 & 0.21 & 0.28 & 0.20 & 0.22 & 0.32 \\
\hline Dy & 1.31 & 1.01 & 1.17 & 0.99 & 0.83 & 1.32 \\
\hline Ho & 0.14 & 0.16 & 0.18 & 0.16 & 0.13 & 0.18 \\
\hline Er & 0.36 & 0.43 & 0.39 & 0.48 & 0.25 & 0.5 \\
\hline Tm & 0.04 & 0.06 & 0.05 & 0.05 & 0.03 & 0.04 \\
\hline $\mathrm{Yb}$ & 0.32 & 0.36 & 0.34 & 0.39 & 0.22 & 0.35 \\
\hline $\mathrm{Lu}$ & 0.03 & 0.05 & 0.05 & 0.05 & 0.03 & 0.04 \\
\hline $\mathrm{K}_{2} \mathrm{O} / \mathrm{Na}_{2} \mathrm{O}$ & 1.09 & 0.79 & 0.36 & 0.25 & 0.68 & 1.04 \\
\hline $\mathrm{La} / \mathrm{Yb}$ & 309.7 & 49.2 & 49.2 & 28.2 & 90.5 & 144.9 \\
\hline $\mathrm{Eu} / \mathrm{Eu}^{*}$ & 0.46 & 0.81 & 0.63 & 1.14 & 0.94 & 0.39 \\
\hline
\end{tabular}

and gradational zones, yielding 17 concordant results (Table 3; Fig. 7a) and 7 that were either discordant and/or have high common $\mathrm{Pb}$. Discordance can be attributed to $\mathrm{Pb}$ loss during recent weathering and/or earlier metamorphic events. The 17 concordant analyses have relatively low-U contents (30-140 ppm), with the exception of grain $03 \mathrm{c}$ (622 ppm), and have Th/U values ranging from 0.43 to 0.97 .
Fourteen concordant analyses scatter along the concordia with ${ }^{207} \mathrm{~Pb} /{ }^{206} \mathrm{~Pb}$ ages ranging from 3336 to $3260 \mathrm{Ma}$. Three analyses are significantly younger, with ${ }^{207} \mathrm{~Pb} /{ }^{206} \mathrm{~Pb}$ ages in the range 3064-3004 Ma. No correlation between zircon structure and age was observed (Fig. 6a). From the 14 concordant analyses, the 7 oldest analyses are statistically equivalent with a weighted mean ${ }^{207} \mathrm{~Pb} /{ }^{206} \mathrm{~Pb}$ age of $3318 \pm 5 \mathrm{Ma}$ 
A

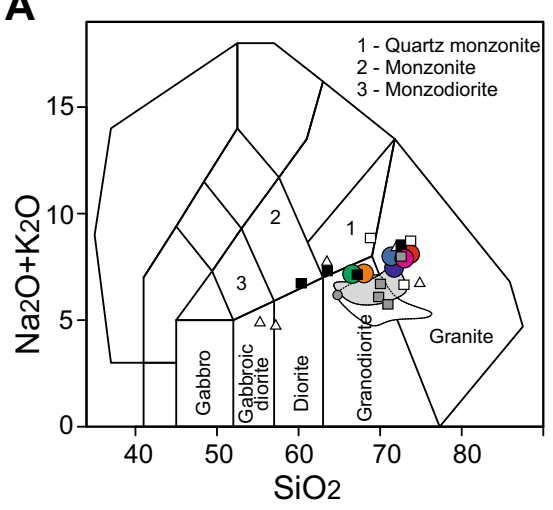

D

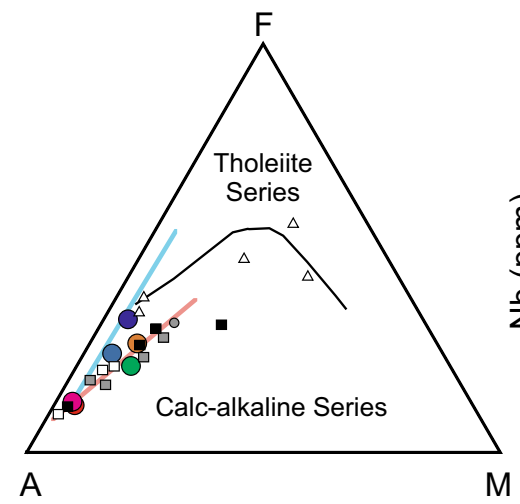

B
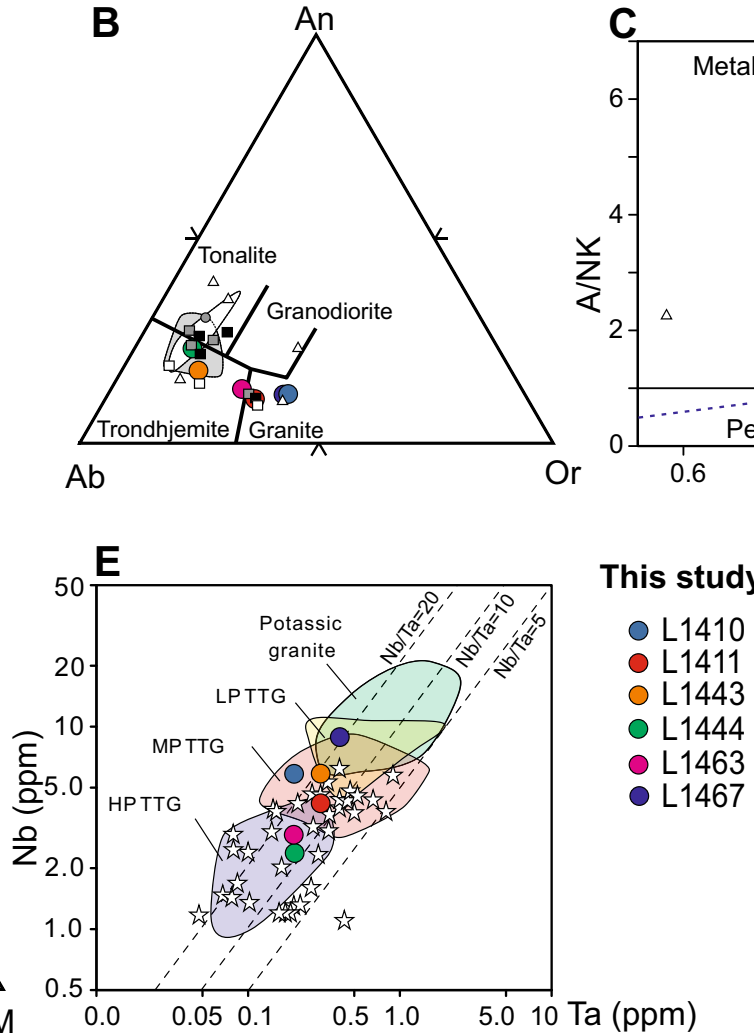

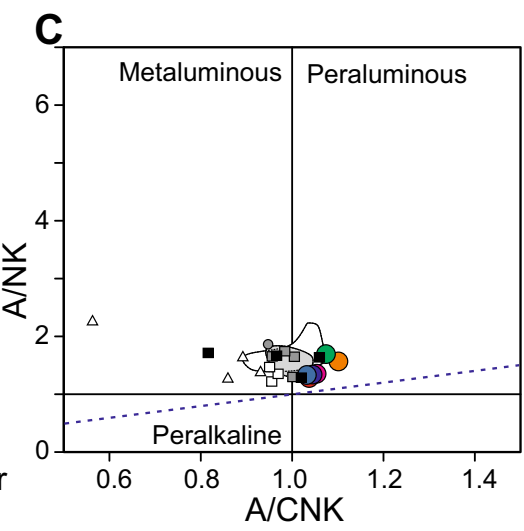

This study: Previous studies:

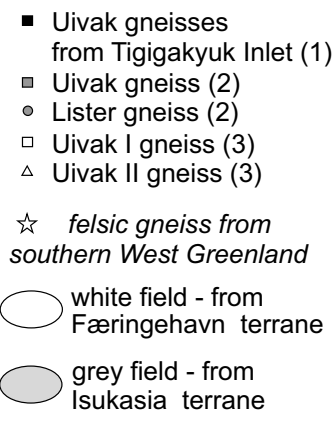

Fig. 4 Major element diagrams for the grey gneisses of the Saglek Block. a Total alkali vs. silica (TAS) diagram (Middlemost 1994); b An-Ab-Or ternary diagram (Barker 1979; after O'Connor 1965); c A/CNK vs. A/NK plot of Shand (1943); d AFM diagram (Irvine and Baragar 1971), $\mathrm{Na}_{2} \mathrm{O}+\mathrm{K}_{2} \mathrm{O}(\mathrm{A}), \mathrm{Fe}_{2} \mathrm{O}_{3}{ }^{*}=$ total $\mathrm{Fe}$ expressed as $\mathrm{Fe}_{2} \mathrm{O}_{3}(\mathrm{~F})$, and $\mathrm{MgO}(\mathrm{M})$; e $\mathrm{Nb} / \mathrm{Ta}$ diagram (Moyen 2011). Data from previous studies are from: 1-Sałacińska et al. (2018); 2-Schiøtte et al. (1989a); 3-Collerson and Bridgwater (1979) and. Data for Færingehavn and Isukasia terranes in West Greenland from Nutman et al. (1996, 1999, 2007), Kamber et al. (2002), Næraa et al. (2012) and Hoffmann et al. (2011, 2014)
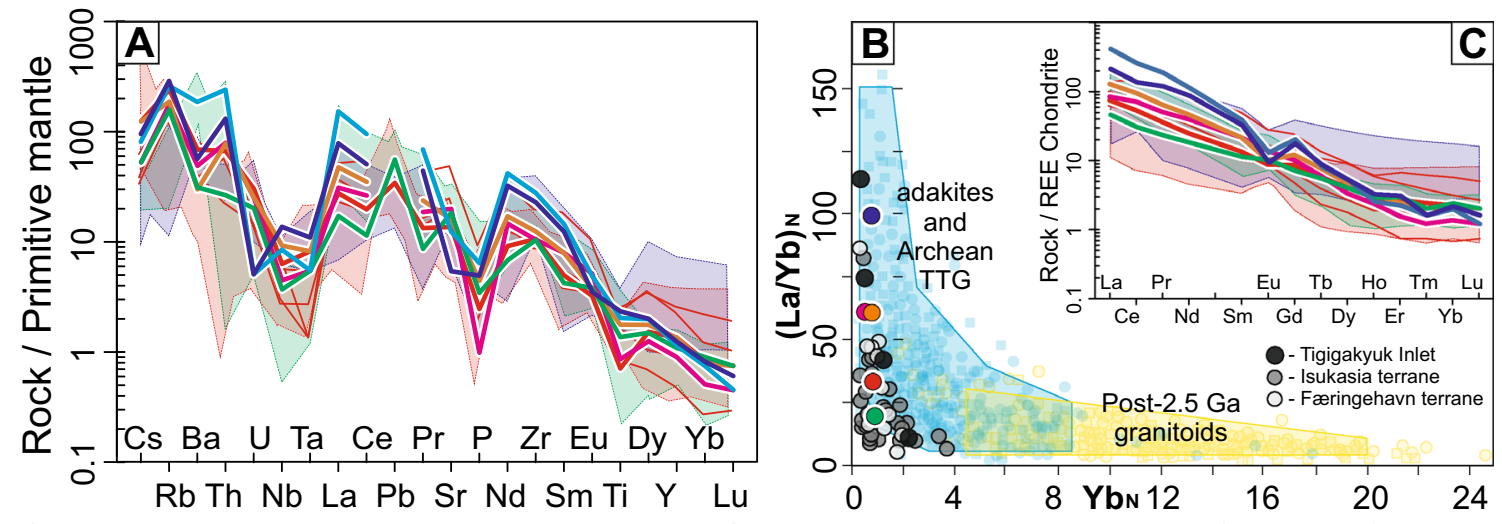

Saglek Block

Paleoarchean gneiss:

—L1410 — L1444 —L1467

Eoarchean gneiss:

—L1411 — L1443 — L1463 — from Tigigakyuk Inlet

\section{West Greenland}

ca. $3.2 \mathrm{Ga}$ gneisses and migmatite

ca. 3.6-3.9 Ga felsic gneisses
Fig. 5 Trace element diagrams for grey gneisses in the Saglek Block. a Primitive mantle-normalized diagram. b $(\mathrm{La} / \mathrm{Yb})_{\mathrm{N}} \mathrm{vs}$. $\mathrm{Yb}_{\mathrm{N}}$ diagram (modified after Martin 1993, and Condie 2005). c Chondrite-normalized REE diagram. Normalization values from McDonough and Sun
(1995). Data for Tigigakyuk Inlet are from Sałacińska et al. (2018); for West Greenland from Nutman et al. (1996, 1999, 2007), Kamber et al. (2002), Næraa et al. (2012), Hoffmann et al. (2011, 2014), and for Tarim Craton in north-west China from Ge et al. (2018) 


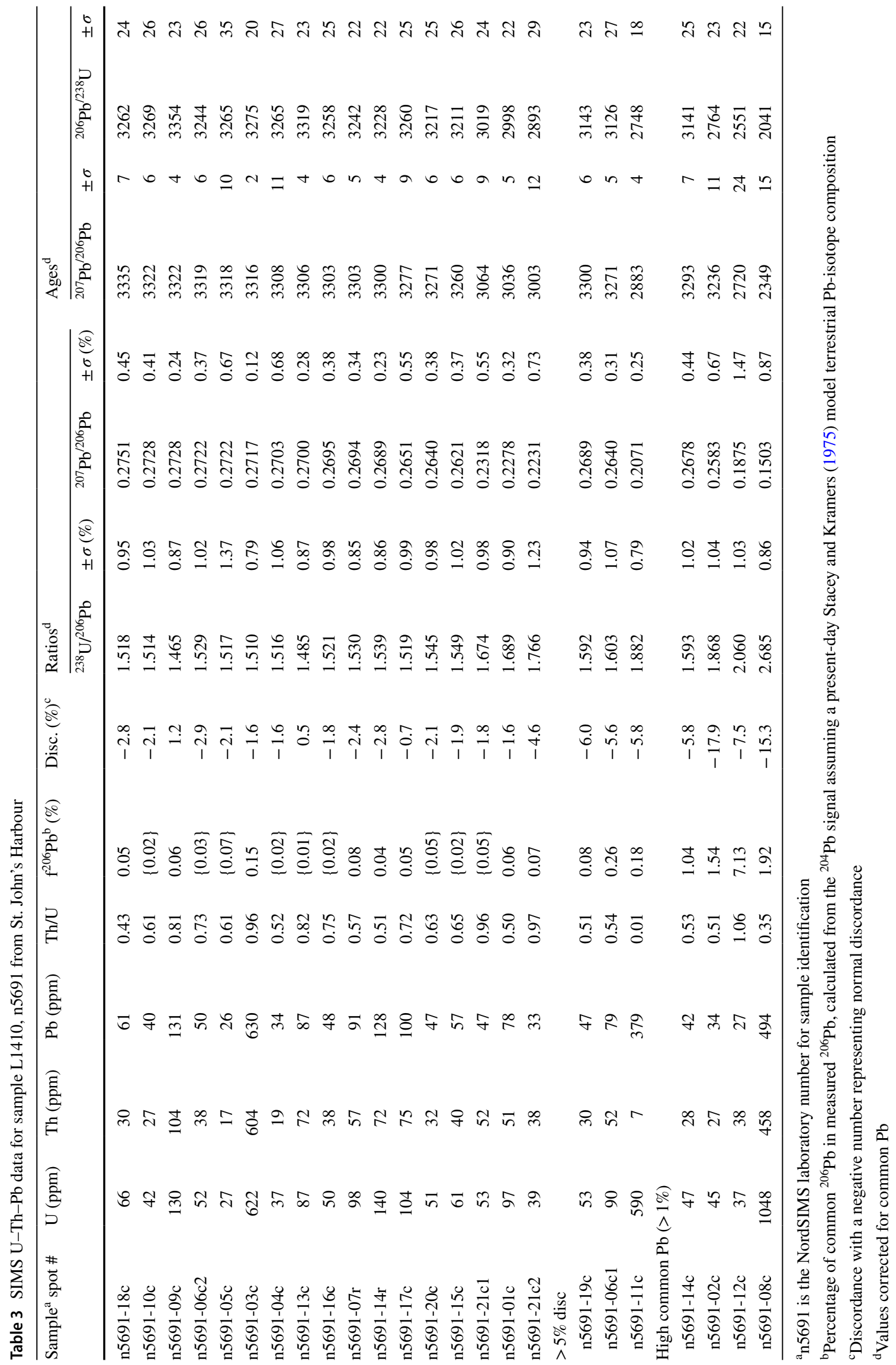




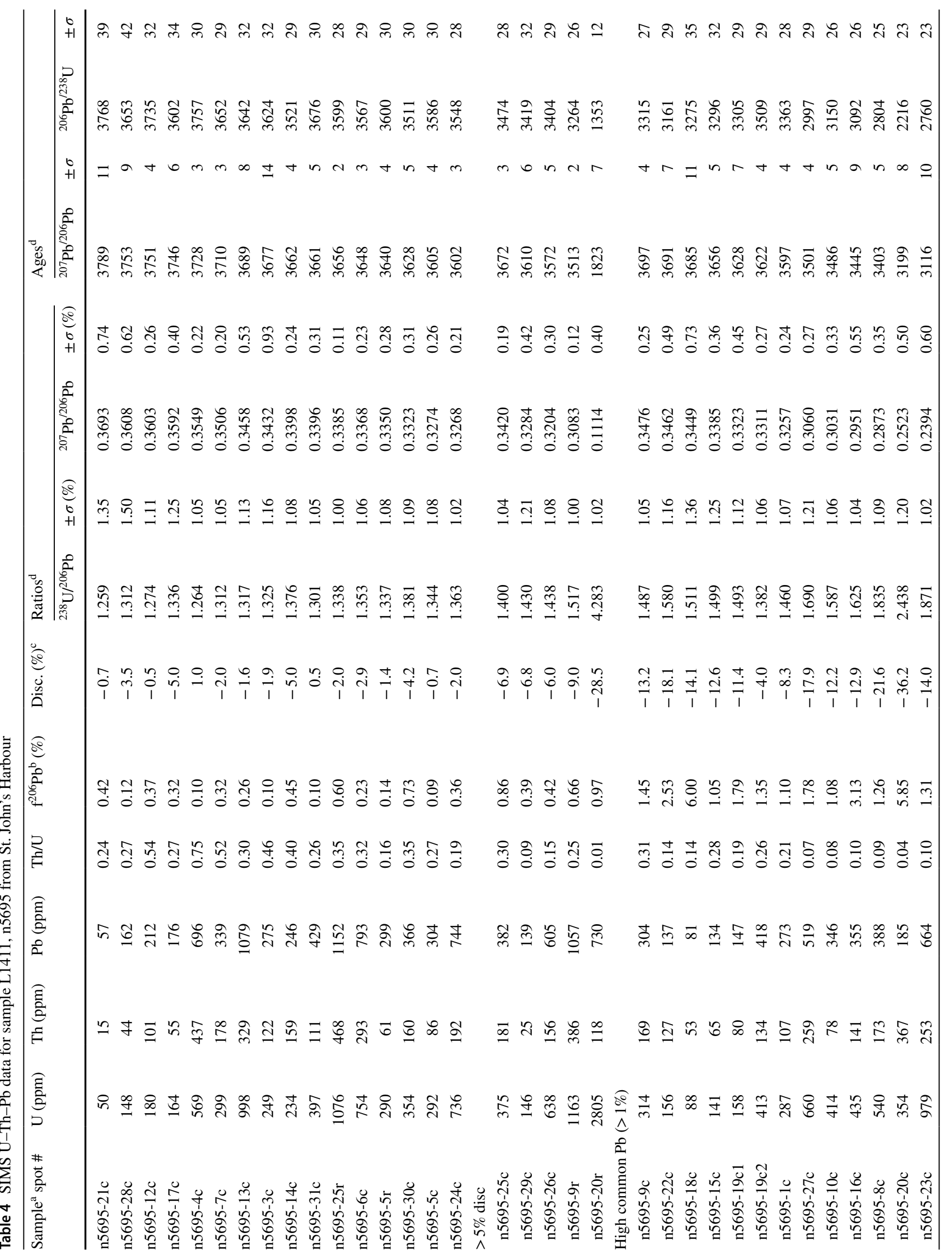


(MSWD =1.7). Of the seven remaining analyses from this group, and the three youngest concordant ones, there is no distinction in composition or structure between these and the older analyses. These data scatter along a Model 2 discordia chord with intercept ages of $2725 \pm 160$ and $3392 \pm 65 \mathrm{Ma}$ (MSWD =1.8). The upper intercept age is slightly older than the weighted mean ${ }^{207} \mathrm{~Pb} /{ }^{206} \mathrm{~Pb}$ age; however, the latter is preferred as the best estimate for the emplacement of the granitic protolith of the gneiss.

Granitic gneiss sample L1411 from St. John's Harbour contains mostly subhedral elongate zircon grains (up to $300 \mu \mathrm{m}$ long, with aspect ratios of 2:1 to 4:1; Fig. 6b). Most are dark in CL, although a few have lighter cores. Thirty-six analyses of 31 grains were obtained (Table 4; Fig. 7b), of which five analyses were discordant due to recent or earlier $\mathrm{Pb}$ loss, and 15 have high common $\mathrm{Pb}$. The remaining 16 analyses were obtained from zones with $\mathrm{Th} / \mathrm{U}$ values ranging from 0.16 to 0.75 , and spread along the concordia with ${ }^{207} \mathrm{~Pb} /{ }^{206} \mathrm{~Pb}$ ages between 3789 and $3602 \mathrm{Ma}$. The oldest age is from a structurally distinct core with low $\mathrm{U}$ (50 ppm) (Fig. 6b, grain 21). Three analyses are from cores with similar $\mathrm{U}$ contents $(148-180 \mathrm{ppm})$ and have ${ }^{207} \mathrm{~Pb} /{ }^{206} \mathrm{~Pb}$ ages of 3753-3746 Ma. The remaining 12 concordant analyses are from non-oscillatory zoned zircon, with highly variable $\mathrm{U}$ contents between 233 and $1076 \mathrm{ppm}$. These have $\mathrm{U}-\mathrm{Pb}$ isotopic compositions resulting in a spread of ages along the concordia from 3728 to $3602 \mathrm{Ma}$. This is a common observation in zircon from high-grade metamorphic rocks (Nutman et al. 1996, 2000; Whitehouse et al. 1999).

Trondhjemitic gneiss sample L1443 from Big Island contains zircons that are subhedral and elongate (100-230 $\mu \mathrm{m}$ length, with aspect ratios of 2:1 to 3:1; Fig. 6c), and strong oscillatory zoning. A total of 32 analyses were obtained from 20 grains (Table 5; Fig. 7c), of which 5 concordant analyses are excluded from further consideration, because they were obtained from mixed domains as revealed by the CL images. Of the remaining data, 10 are discordant and 17 have high common $\mathrm{Pb}$ of which 6 are also discordant. Discordance can be attributed to recent or earlier disturbance. Ten concordant analyses from 7 zircon grains spread along the concordia with ${ }^{207} \mathrm{~Pb} /{ }^{206} \mathrm{~Pb}$ ages ranging from 3759 to $3730 \mathrm{Ma}$. These zircon grains have variable U contents (126-422 ppm) and Th/U ratios (0.09-0.67). The six oldest analyses are statistically equivalent, with a weighted mean ${ }^{207} \mathrm{~Pb} /{ }^{206} \mathrm{~Pb}$ age of $3746 \pm 5 \mathrm{Ma}(\mathrm{MSWD}=1.5)$, whereas the remaining four concordant data range to lower ages, which are interpreted as being affected by $\mathrm{Pb}$ loss.

Trondhjemitic gneiss sample L1444 from Big Island contains mostly subhedral, elongate zircons (up to $250 \mu \mathrm{m}$ with an average aspect ratio of 2:1) with strong oscillatory zoning. They have thin rims that transgress the primary structures (Fig. 6d). Nineteen analyses from ten grains were obtained (Table 6; Fig. 7d), including nine concordant data and ten 


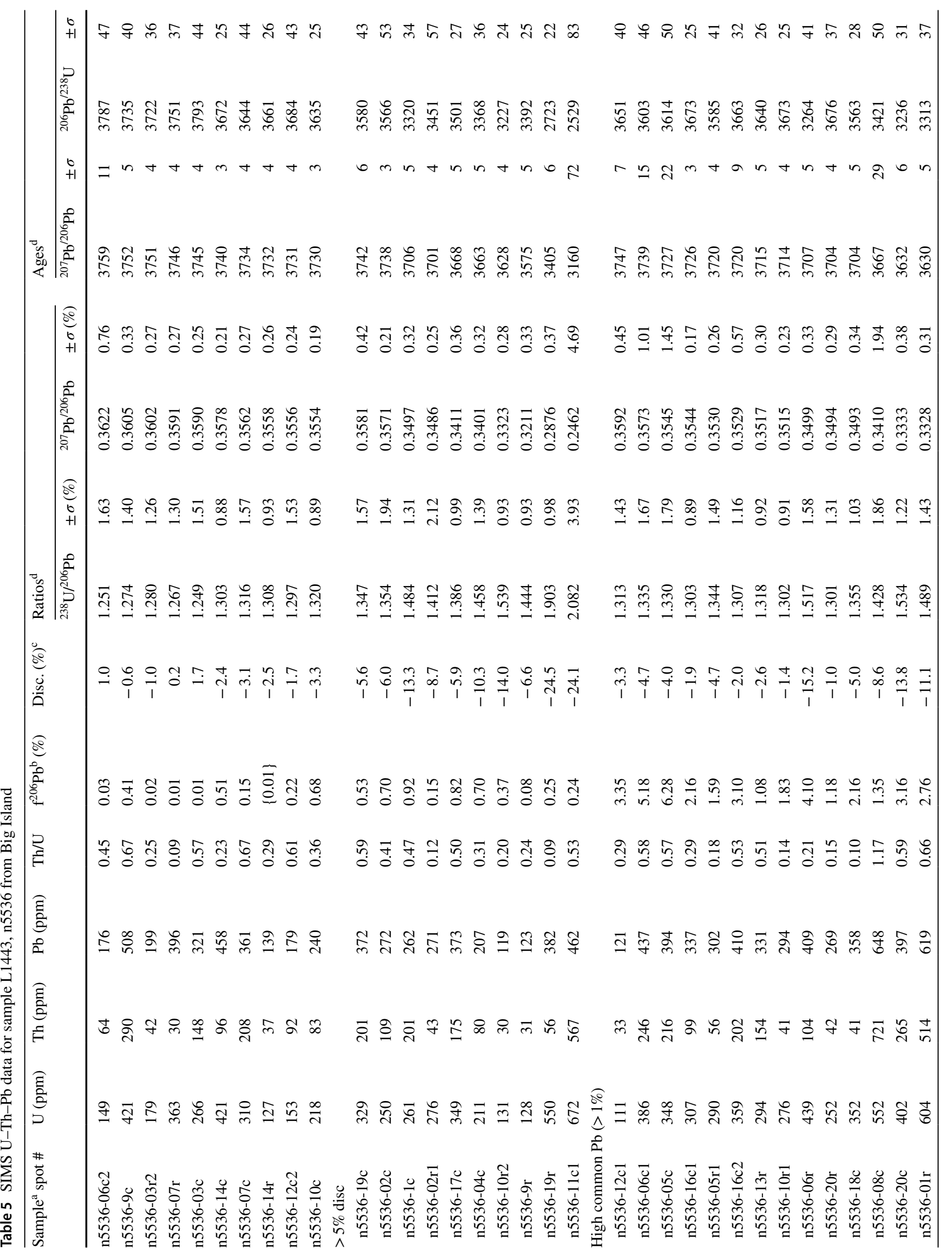




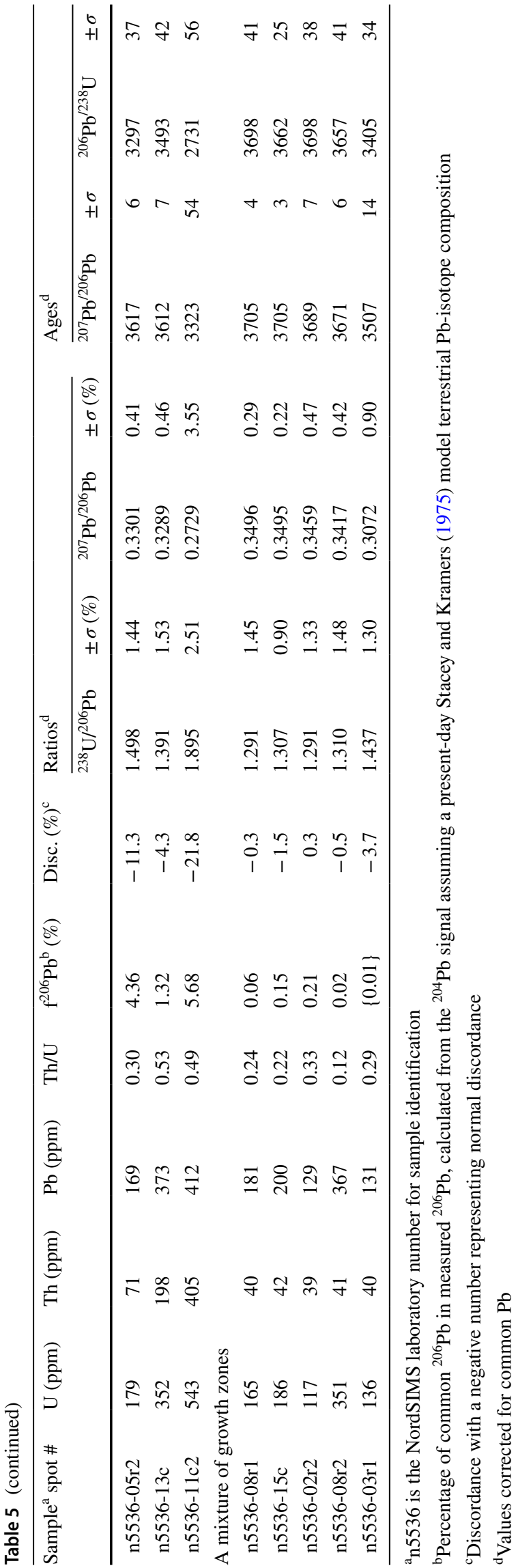

data with high common $\mathrm{Pb}$ contents. The zircon grains have variable $\mathrm{U}$ contents $(78-508 \mathrm{ppm})$ and $\mathrm{Th} / \mathrm{U}$ ratios ranging from 0.38 to 0.55 . Two concordant analyses with ${ }^{207} \mathrm{~Pb} /{ }^{206} \mathrm{~Pb}$ ages of $3174 \mathrm{Ma}$ and $3160 \mathrm{Ma}$ were obtained from mixed zones and over cracks, and were, therefore, excluded from further consideration. The remaining seven concordant data define a weighted mean ${ }^{207} \mathrm{~Pb} /{ }^{206} \mathrm{~Pb}$ age of $3219 \pm 7 \mathrm{Ma}$ $(\mathrm{MSWD}=1.4)$.

Trondhjemitic gneiss sample L1463 from Little Island contains zircons that are mostly subhedral and elongate (up to $250 \mu \mathrm{m}$ in length and with aspect ratios of $2: 1$ to $3: 1$; Fig. 6e), and show oscillatory zoning in CL. Most grains have a thick, dark-CL rim and areas of disrupted oscillatory zoning. Thirty-eight analyses were made on 23 grains, of which five were identified as mixed zones in post-analytical CL imaging, and are, therefore, excluded from further consideration. Nineteen of the remaining analyses are discordant and/or have high common $\mathrm{Pb}$, and the wide scatter can be attributed to isotopic disturbance ( $\mathrm{Pb}$ loss) at or after 2.7 Ga. Fourteen analyses are concordant (Table 7; Fig. 7e) and spread along the concordia with ${ }^{207} \mathrm{~Pb} /{ }^{206} \mathrm{~Pb}$ ages ranging from 3749 to $3517 \mathrm{Ma}$. Of these, two analyses were obtained from a CL-bright core with low-U contents (44 and $22 \mathrm{ppm}$, respectively) and yield ${ }^{207} \mathrm{~Pb} /{ }^{206} \mathrm{~Pb}$ ages of $3749 \mathrm{Ma}$ and $3675 \mathrm{Ma}$ (Fig. 7e). Five analyses from oscillatory zoned cores, with ${ }^{207} \mathrm{~Pb} /{ }^{206} \mathrm{~Pb}$ ages ranging from 3725 to $3713 \mathrm{Ma}$ form a significant cluster on concordia, with a weighted mean ${ }^{207} \mathrm{~Pb} /{ }^{206} \mathrm{~Pb}$ age of $3717 \pm 6 \mathrm{Ma}(\mathrm{MSWD}=2.4)$. Four concordant analyses (3703 Ma, $3696 \mathrm{Ma}, 3691 \mathrm{Ma}$ and $3517 \mathrm{Ma}$ ) are on areas of prismatic zircon in the cores of grains with morphologies and compositions similar to those that form the cluster at ca. $3717 \mathrm{Ma}$. Additionally, three analyses from dark-CL rims (Fig. 7e), with high-U contents (936-1046 ppm) have ${ }^{207} \mathrm{~Pb} /{ }^{206} \mathrm{~Pb}$ ages ranging from 3634 to $3562 \mathrm{Ma}$.

Granitic gneiss sample L1467 from Maidmonts Island mostly contains subhedral, stubby to elongate zircon grains (up to $380 \mu \mathrm{m}$ in length, with aspect ratios of $2: 1$ to $3: 1$; Fig. 6f). Some zircon grains have unzoned, CL-dark cores with distinct boundaries and surrounded by oscillatory zoned or unzoned zircon, or else they are zoned with relatively CLbright cores showing a gradation to CL-dark rims (Fig. 6f). Twenty-eight analyses from 27 grains were obtained (Table 8; Fig. 7f), of which 11 are discordant or have high common $\mathrm{Pb}$. Seventeen concordant analyses spread along concordia with ${ }^{207} \mathrm{~Pb} /{ }^{206} \mathrm{~Pb}$ ages ranging from 3328 to $3256 \mathrm{Ma}$. These zircons have a range of $\mathrm{U}$ contents between 36 and $1250 \mathrm{ppm}$, and $\mathrm{Th} / \mathrm{U}$ ratios from 0.58 to 0.97 . Of these, the ten oldest concordant analyses yield a weighted mean ${ }^{207} \mathrm{~Pb} /{ }^{206} \mathrm{~Pb}$ age of $3325 \pm 3 \mathrm{Ma}(\mathrm{MSWD}=1.4)$. The remaining seven concordant analyses have similar structure to the ca. $3325 \mathrm{Ma}$ zircon but are slightly younger. The age 


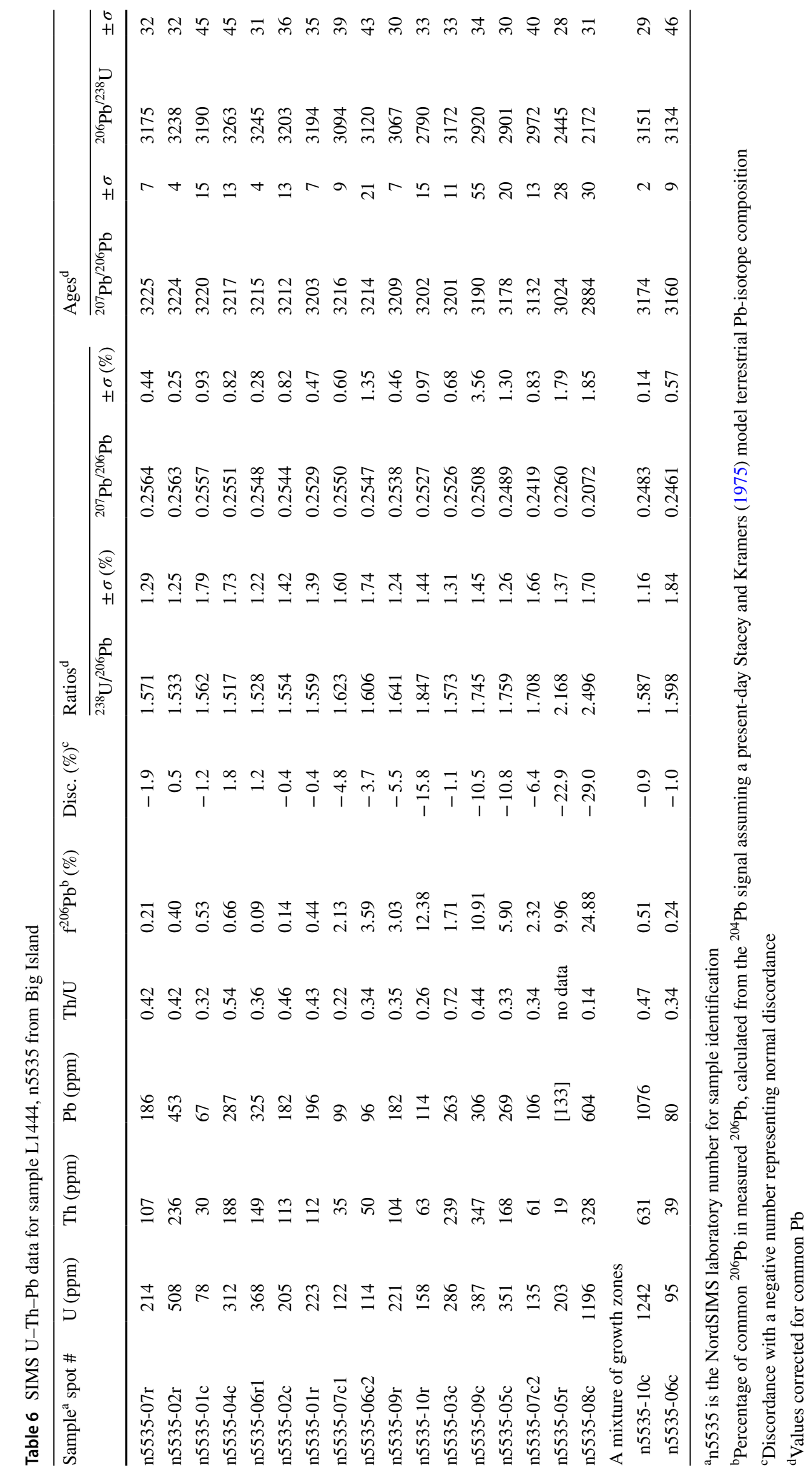




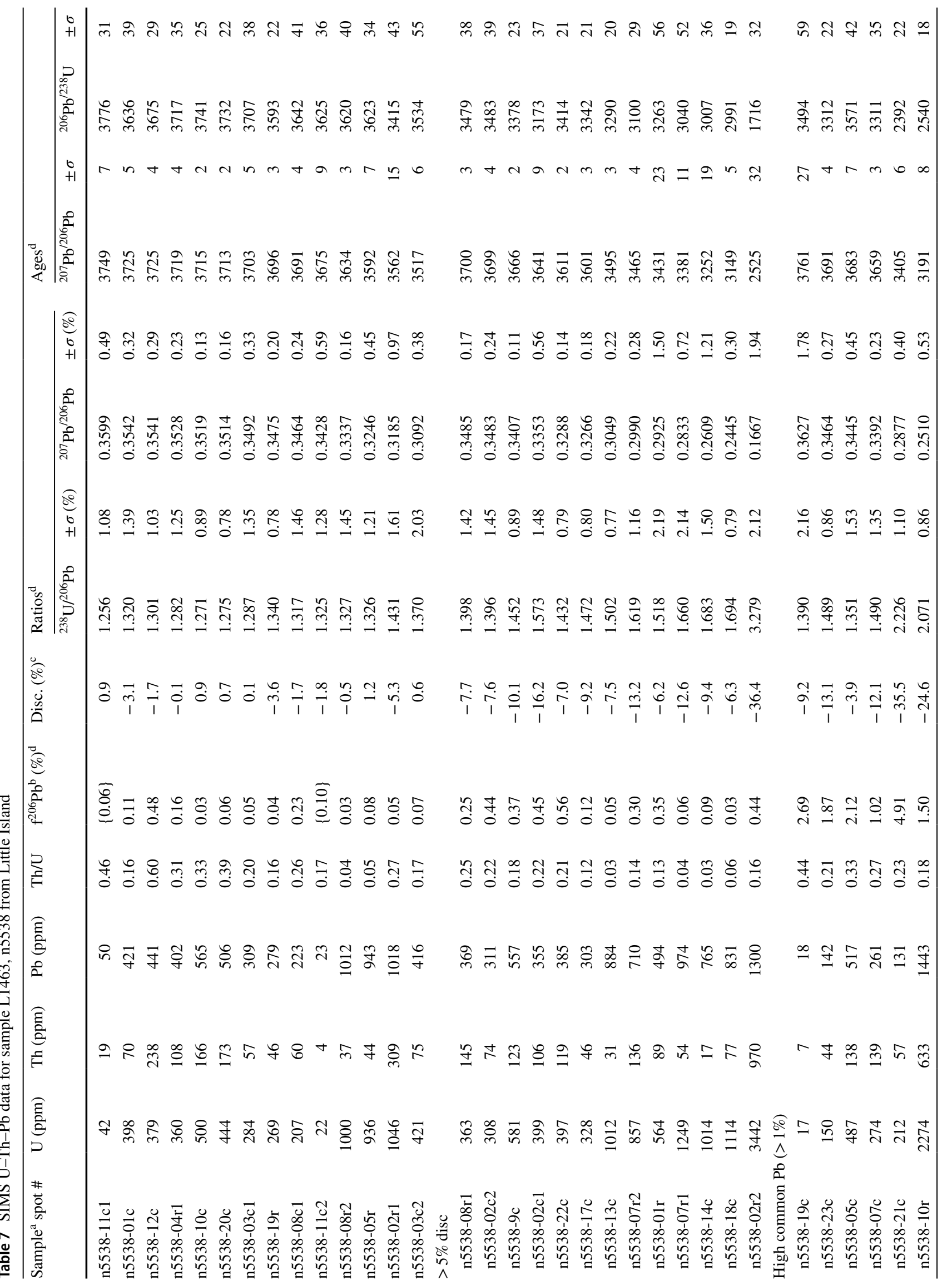




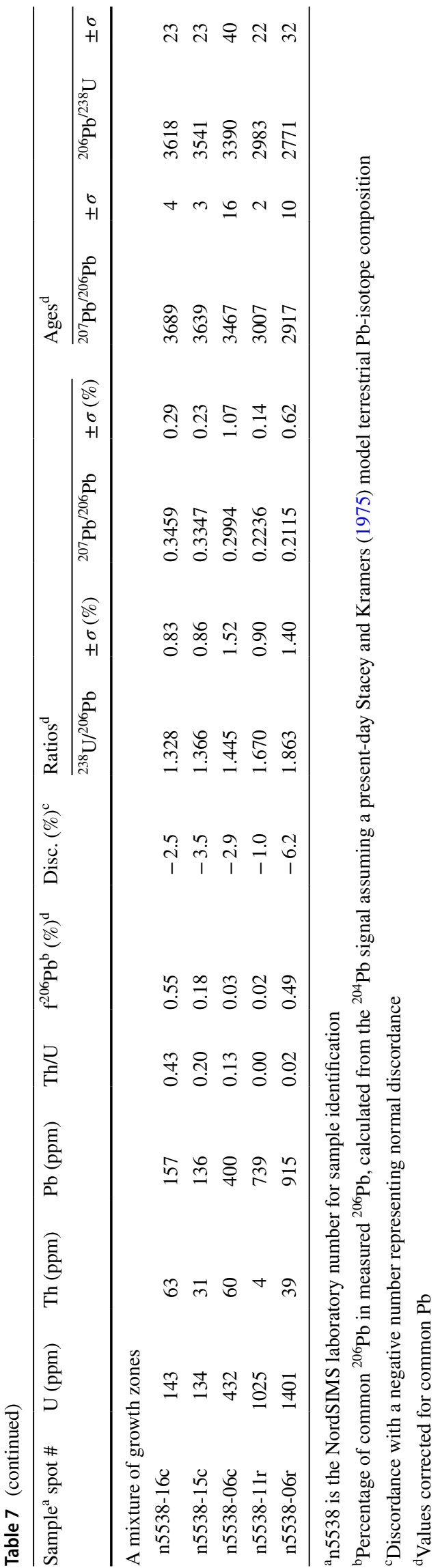

difference is interpreted as being the result of $\mathrm{Pb}$ loss during later metamorphism at ca. $2.7 \mathrm{Ga}$.

\section{Interpretation}

\section{Geochemistry}

The grey gneisses in the Saglek Block are extensively recrystallised and deformed as a result of several later events, including upper amphibolite to granulite facies regional metamorphism (Collerson and Bridgwater 1979; Schiøtte et al. 1989a). Consequently, the primary magmatic composition of rocks may have been altered. Metamorphism and hydrothermal alteration can affect large ion lithophile elements (LILEs), including $\mathrm{Rb}, \mathrm{Ba}, \mathrm{K}, \mathrm{Sr}, \mathrm{Pb}$ and $\mathrm{Th}$, as well as LREEs. In contrast, high field strength elements (HFSEs) and HREEs are relatively immobile (Alderton et al. 1980; Ward et al. 1992; Condie and Sinha 1996; Polat and Hofmann 2003).

The whole-rock geochemistry, including major and trace element compositions, distinguishes two types of gneisses: trondhjemitic gneiss (L1411, L1443, L1444, L1463) and granitic gneiss (L1410, L1467). TTG gneisses vary from trondhjemitic to borderline granitic in composition (Fig. 4b). These have strongly fractionated REE patterns without Eu anomalies, and have negative $\mathrm{Nb}$, Ta, $\mathrm{P}$ and $\mathrm{Ti}$ anomalies. All of these features are typical of Archean TTG, although L1411 has a higher $\mathrm{K}_{2} \mathrm{O}$ content. In contrast, the granitic gneisses L1410 and L1467 are characterized by higher $\mathrm{Na}_{2} \mathrm{O} / \mathrm{K}_{2} \mathrm{O}$ ratios, extreme enrichment in LREE, high $\mathrm{La} / \mathrm{Yb}$ ratios and negative $\mathrm{Eu}$ anomalies.

Experimental studies on partial melting of hydrous metabasalt as a source for TTG show that HFSEs are largely controlled by mineral assemblages in the restite. The fractionated REE pattern requires the presence of garnet in the source (Martin 1987; Drummond and Defant 1990; Rapp et al. 1991; Moyen and Stevens 2006) for which both garnet amphibolite (Foley et al. 2002) and eclogite (Rapp et al. 2003) provide reasonable solutions. The negative $\mathrm{Nb}$, $\mathrm{Ta}$ and $\mathrm{Ti}$ anomalies have been attributed by Martin et al. (2005) and Hoffmann et al. (2011) to the presence of residual amphibole and/or Fe-Ti oxides (rutile, ilmenite).

Samples L1410 and L1467 (granitic gneisses) have significant negative Eu anomalies, which indicate that plagioclase played a role in magma genesis, either as a residual phase after partial melting of source rocks and/or removal from the magma during fractional crystallization. In contrast, the trondhjemitic gneisses lack Eu anomalies, and have $\mathrm{Ta}$ and $\mathrm{Nb}$ contents typical of medium-pressure (L1411, L1443) or high-pressure (L1444 and L1463) TTG 


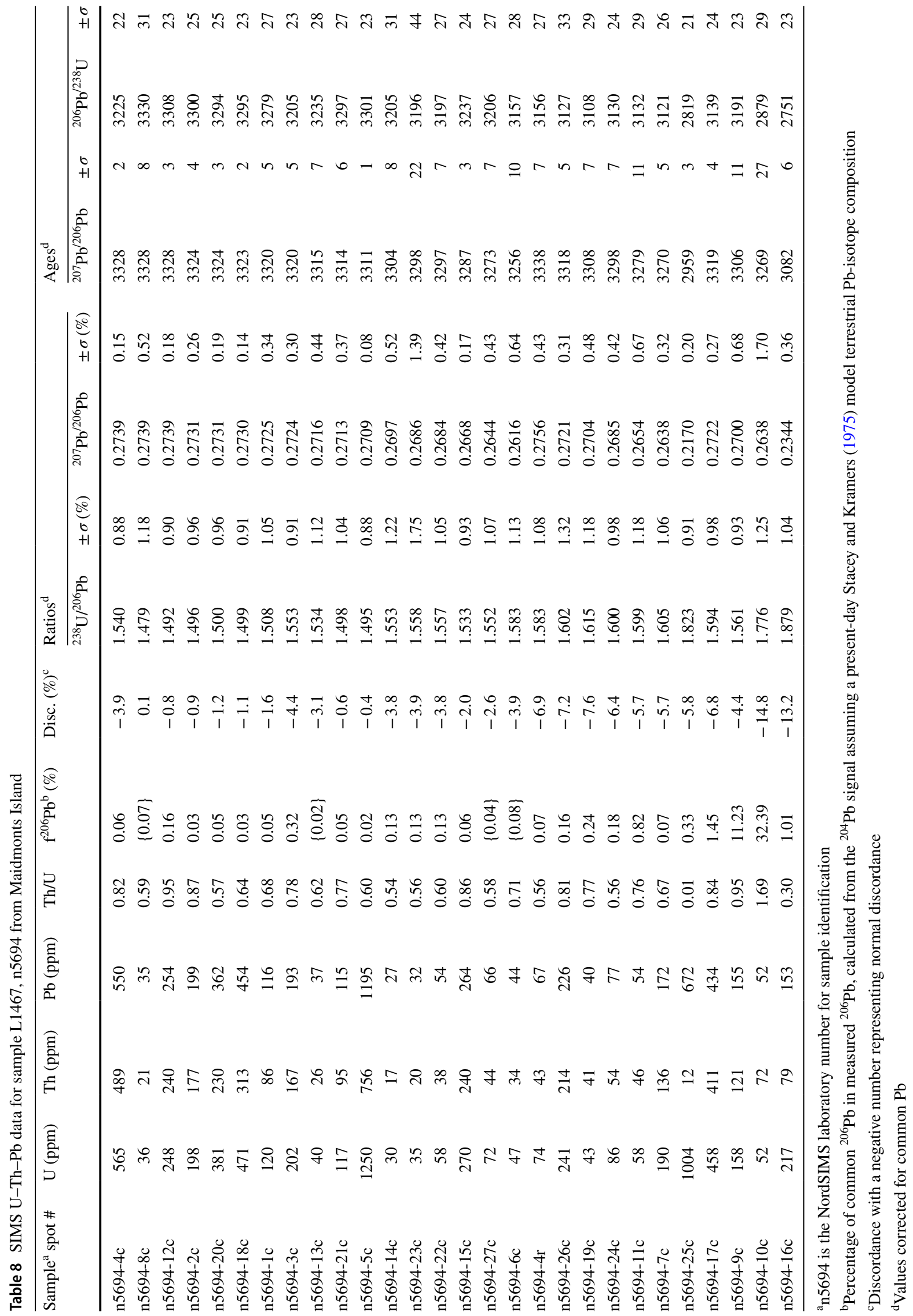




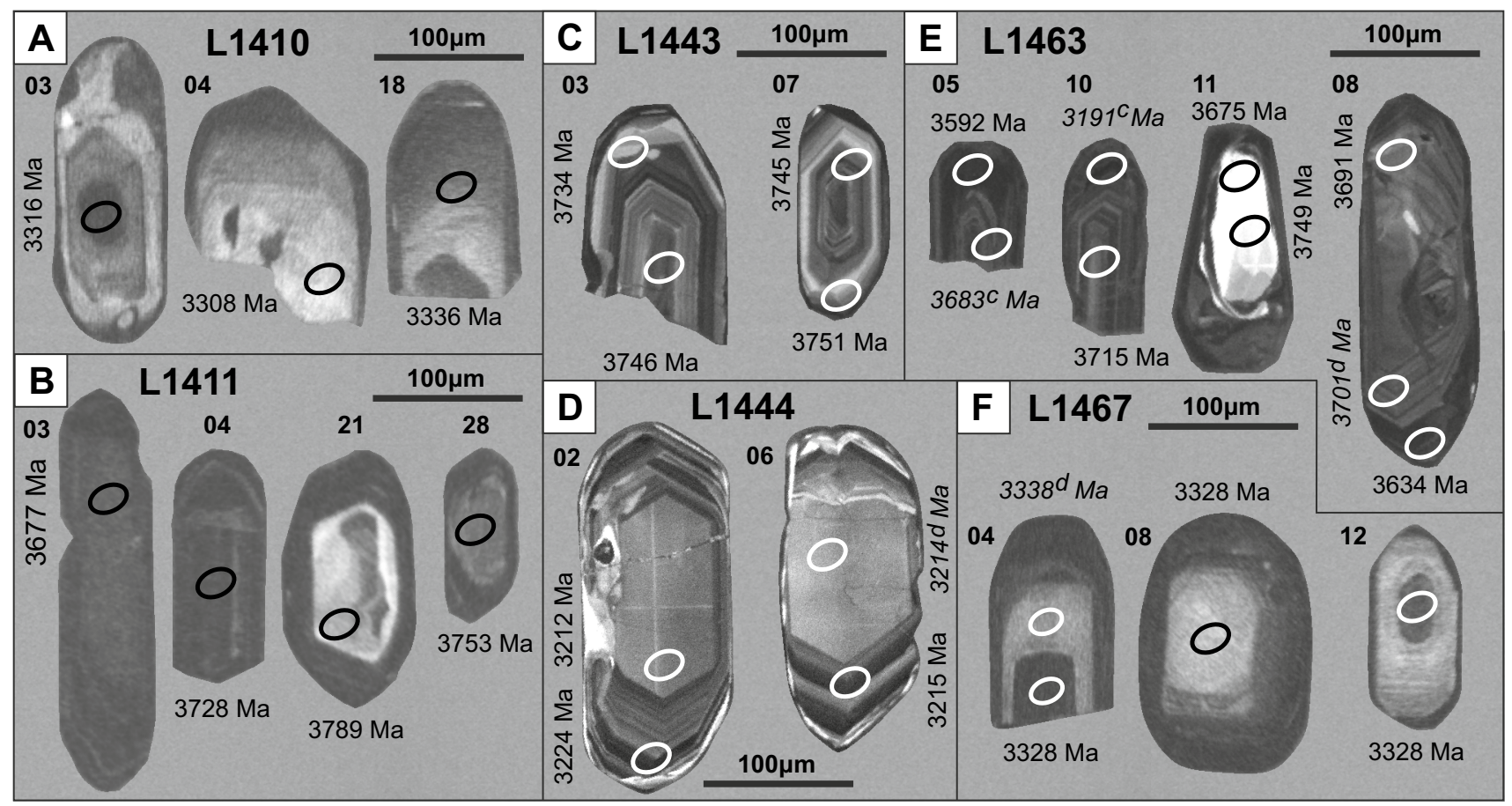

Fig. 6 CL images of zircons from: a sample L1410; b sample L1411; c sample L1443; d sample L1444; e sample L1463; f sample L1467. Ages $\left({ }^{207} \mathrm{~Pb} /{ }^{206} \mathrm{~Pb}\right) ; c$ high common $\mathrm{Pb}(>1 \%) ; d$ discordant $(>5 \%)$

rocks (Fig. 4e). Partial melting of mafic crust with residual amphibole and garnet, and little or no rutile or plagioclase, can produce medium-pressure TTG, whereas highpressure TTG can be produced by the melting of mafic crust leaving residual garnet and rutile, with no amphibole or plagioclase. In contrast, the granitic gneisses (L1410 and L1467) with Eu anomalies, can be classified as high LREE, being transitional sodic (low-pressure) to potassic (higher LILE) types. The latter can be produced by partial melting within continental crust. This suggests that an earlier crustal component played an important role in formation of these rocks.

\section{Geochronology}

The oldest age population from the samples studied was found in trondhjemitic gneiss L1443 from Big Island (Fig. 7c), which yielded a magmatic age of $3746 \pm 5 \mathrm{Ma}$ from oscillatory zoned zircon typical of that crystallized from a felsic magma. Consequently, this age is interpreted as the crystallization age of the trondhjemitic orthogneiss protolith.

Sample L1463 from Little Island shows a more complex age distribution, with a range of ${ }^{207} \mathrm{~Pb} /{ }^{206} \mathrm{~Pb}$ ages from 3749 to $3517 \mathrm{Ma}$, and a sub-population of five oscillatory zoned, magmatic cores that yielded a mean age of $3717 \pm 6$ Ma that we interpret as the time of protolith crystallization (Fig. 7e). An older core with a low $\mathrm{U}$ content is interpreted as zircon inherited from crustal sources, whereas younger cores are interpreted as being affected by $\mathrm{Pb}$ loss. High-U rims scatter around ca. $3.6 \mathrm{Ga}$ in age and correspond to previous estimates for the timing of high-T metamorphism in the area (Schiøtte et al. 1989a; Sałacińska et al. 2018).

In the case of granitic gneiss sample L1411 from St. John's Harbour, no clear age for the igneous protolith was obtained (Fig. 7b). However, weakly zoned zircon recorded ages that scattered between 3753 to $3602 \mathrm{Ma}$. This may be due to disturbance during metamorphism at ca. $3.6 \mathrm{Ga}$ (Sałacińska et al. 2018). However, considering the banded nature of the sample, it is also possible that zircons were derived from more than one protolith.

The trondhjemitic gneiss sample L1444 from Big Island contains zircon with oscillatory zones (Fig. 6d) typical of igneous growth; therefore, the weighted mean age of $3219 \pm 7 \mathrm{Ma}$ is interpreted as the age of the magmatic protolith. This sample is significantly younger than other TTG gneisses, and is similar in age to the Lister gneiss (Schiøtte et al. 1989a).

Granitic gneiss sample L1410 from St. John's Harbour contains zircon with CL-dark weakly zoned cores and distinct bright rims (Fig. 6a). The oldest weighted mean ${ }^{207} \mathrm{~Pb} /{ }^{206} \mathrm{~Pb}$ age of $3318 \pm 5 \mathrm{Ma}$ is interpreted as the crystallization age of the magmatic protolith (Fig. 7a). Assuming that the older age $(3318 \pm 5 \mathrm{Ma})$ represents the time of zircon crystallization, the younger data may have been affected by $\mathrm{Pb}$ loss during a major metamorphic event at ca. 

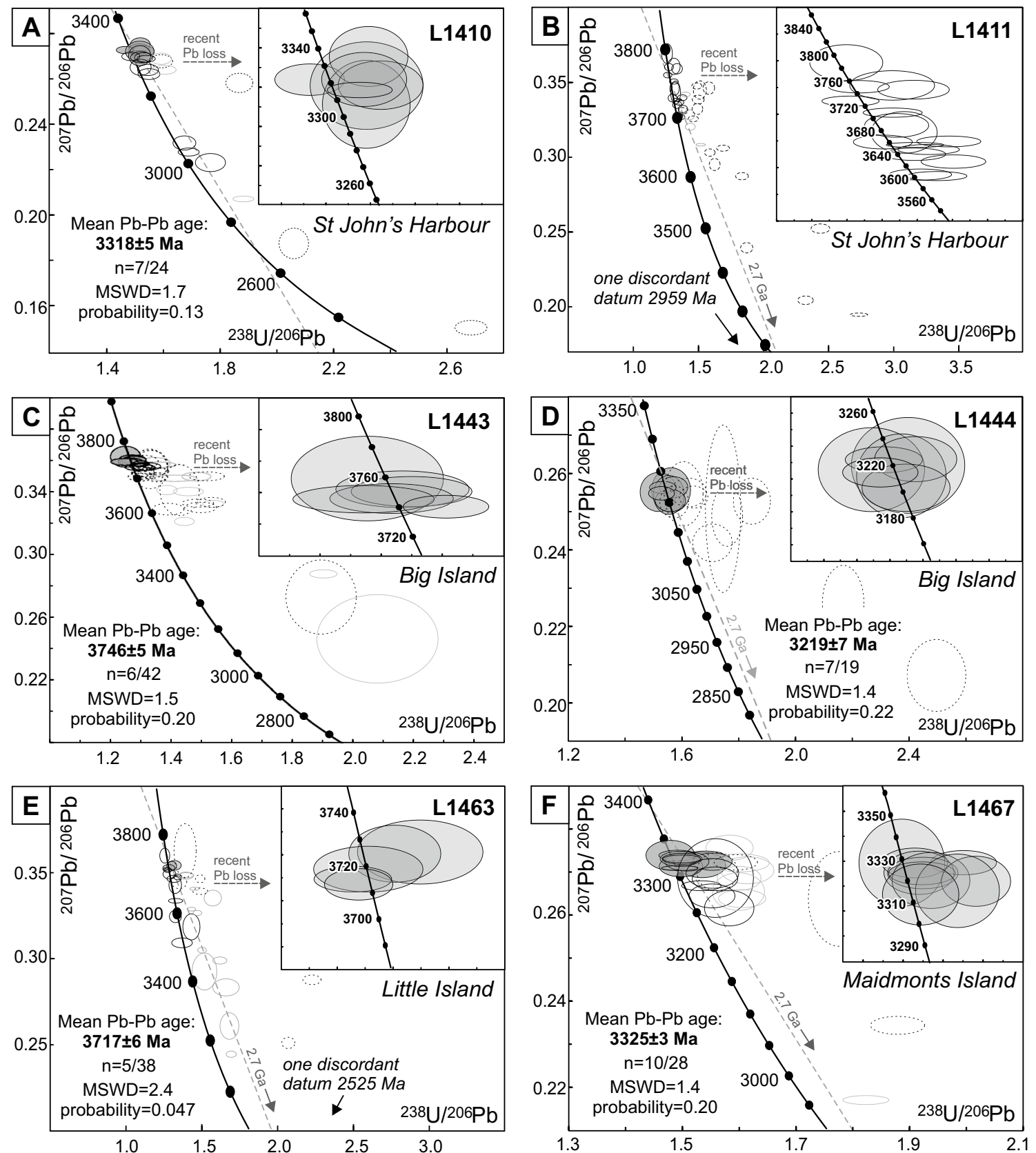

Fig. 7 SIMS zircon U-Pb analyses on Tera-Wasserburg plots; a sample L1410; b sample L1411; c sample L1443; d sample L1444; e sample L1463; f sample L1467. Black ellipse outline-concordant data $(<5 \%)$; grey ellipse outline-discordant data $(>5 \%)$; dotted

ellipse outline-high common $\mathrm{Pb}$ data ( $>1 \%)$; filled ellipse-used for age calculation; analyses of mixed domains are not shown. All data-point error ellipses are $2 \sigma$

2.7 Ga (Schiøtte et al. 1989a; Krogh and Kamo 2006). Similarly, the oldest population of zircon from granitic gneiss L1467 from Maidmonts Island, which includes oscillatory zoned and unzoned cores (Fig. 6f), yields a weighted mean ${ }^{207} \mathrm{~Pb} /{ }^{206} \mathrm{~Pb}$ age of $3325 \pm 3 \mathrm{Ma}$, which is interpreted as the time of granite emplacement.

These results show that the orthogneisses can be separated into two groups: an older set with Eoarchean magmatic ages and indication of metamorphism at ca. $3.6 \mathrm{Ga}$; and two younger granitic gneisses with ages of ca. $3.3 \mathrm{Ga}$. The former are all grey orthogneisses and match published ages and descriptions of Uivak I gneiss (Kusiak et al. 2018; Sałacińska et al. 2018 and references therein). The two younger samples are of homogeneous grey gneiss (L1410) and porphyroblastic augen gneiss (L1467), but their geochemistry and zircon internal structures are similar and the 
equivalent ages ( $3318 \pm 5 \mathrm{Ma}$ and $3325 \pm 3 \mathrm{Ma}$, respectively) suggest that they were co-genetic. Taking into account intrusive relationships between porphyroblastic gneiss and grey gneiss observed on Maidmonts Island (Fig. 3), these younger samples are interpreted as representative of Uivak II gneiss.

\section{Discussion}

The Eoarchean (>ca. 3.6 Ga) Uivak gneiss consists of a diverse suite of rocks, ranging from fine-grained to weakly porphyroclastic, homogeneous to banded and of felsic composition. Igneous protoliths underwent deformation and metamorphism up to granulite facies, which resulted in their gneissosity. From initial field observations (Bridgwater et al. 1975; Bridgwater and Collerson 1976; Collerson and Bridgwater 1979), as well as the detailed examination of zircons with complex core/mantle/rim structures (e.g., Schiøtte et al. 1989a; Sałacińska et al. 2018, and this study), a high-T metamorphic event at ca. 3.6 Ga was identified. This tectonothermal event pre-dates emplacement of the Uivak II gneiss, and is confirmed by our field observations on Maidmonts Island (Fig. 3), where porphyritic granite (the precursor to Uivak II gneiss) crosscuts strongly deformed grey gneiss (Uivak I gneiss). The ca. 3.75-3.70 Ga and ca. 3.6 Ga events were also recorded in zircon xenocrysts in ca. $3.56 \mathrm{Ga}$ monzonitic gneiss from Tigigakyuk Inlet (Sałacińska et al. 2018), which was, therefore, intruded shortly after the metamorphic event that produced the Uivak I gneiss.

The protoliths of subsequent Paleoarchean gneisses formed during at least two unrelated magmatic events, at ca. 3.3 Ga and ca. 3.2 Ga. Emplacement of gneissic protoliths at $3.3 \mathrm{Ga}$ was identified in this study, as well as by Krogh and Kamo (2006) and Komiya et al. (2017); (Fig. 8). The emplacement of gneissic protoliths at ca. 3.2 Ga has been referred to as Lister gneiss (Schiøtte et al. 1989a, 1990). However, both Paleoarchean protoliths were grouped together as Lister gneiss by Komiya et al. (2017). But, here we distinguish these two generations on the basis of their distinct ages and geochemistry.

The porphyroblastic gneiss collected from Maidmonts Island recorded an age of $3325 \pm 3 \mathrm{Ma}$ (sample L1467). Gneisses with similar ages were also identified from St. John's Harbour (sample L1410), Nulliak Island and the adjacent coast (Komiya et al. 2017), and from Little Island (Krogh and Kamo 2006). All of these localities were mapped as Uivak II gneiss in previous studies (Bridgwater et al. 1975; Hurst et al. 1975; Bridgwater and Collerson 1976; Collerson and Bridgwater 1979). Intrusive relationships between ca. $3.3 \mathrm{Ga}$ and older (Uivak I) gneisses were recognized on Maidmonts Island (Fig. 3) and Little Island (Krogh and Kamo 2006). The latter study identified ca. 3.35 Ga orthogneiss (DB82.12; a deformed porphyritic granodiorite) that locally crosscut the foliation of the grey gneissic host. The host (DB82.74.1; a moderately layered tonalitic to granodioritic gneiss) was dated by Schiøtte et al. (1989a) at ca. $3.73 \mathrm{Ga}$, consistent with the protoliths of Uivak I gneiss. The occurrence of xenocrysts with ages of ca. $3.76 \mathrm{Ga}$ (LAD282; Komiya et al. 2017) and ca. 3.83-3.66 Ga (TK-89-5; Krogh and Kamo 2006) in ca. $3.3 \mathrm{Ga}$ gneisses, as well as the geochemistry presented here (Fig. 5), indicate crustal involvement in the petrogenesis of this suite. Age equivalents of ca. $3.3 \mathrm{Ga}$ granitic gneisses from the Saglek Block are unknown in south West Greenland, where there is a gap in felsic magmatism between ca. 3.55 and 3.26 Ga (Næraa et al. 2012). The Uivak II gneiss was originally correlated with the ca. 3.6 Ga iron-rich suite of Amîtsoq gneiss from the Nuuk region (Nutman et al. 1984), which contains a distinctive group of augen gneisses and ferrodiorites of mixed crustal and mantle origin. However, the new $3.3 \mathrm{Ga}$ age disproves this correlation.

The TTG gneisses in this study include ca. 3.22 Ga trondhjemitic gneiss from Big Island (sample L1444), which has similar geochemical characteristics to the ca. 3.7 Ga TTG gneisses. A lack of observed intrusive relationships between the older Uivak I and younger Lister gneisses and a lack of zircon inheritance in ca. 3.2 Ga Lister gneiss (Schiøtte et al. 1989a, 1990; Wasteneys et al. 1996; Komiya et al. 2017; this study), as well as the geochemistry, are consistent with the hypothesis proposed by Bridgwater and Schiøtte (1991) and Wasteneys et al. (1996) that the ca. 3.2 and ca. 3.7 Ga crustal rocks were not associated prior to late Archean tectono-metamorphism.

Following the model of Moyen (2011), the protoliths of the Eoarchean gneiss in the Saglek Block could have formed by partial melting of mafic crust under medium- or highpressure conditions, with garnet and rutile, but no plagioclase, in the restite. The presence of inherited zircon cores (Fig. 6b, e), with ages comparable to parts of the Uivak I gneiss, is evidence of an additional, local crustal component. Trace element patterns of the orthogneisses from both the Saglek Block and southern West Greenland are broadly similar; however, individual samples display a different degree of REE fractionation (Fig. 5). Hoffmann et al. (2011) have proposed a tectonic model involving re-melting of thickened island-arc crust in a vertical tectonic regime for the generation of medium-pressure TTG in southern West Greenland. However, the higher pressure TTG with stronger REE fractionation patterns found in some Saglek samples bears a closer resemblance to ca. 3.7 Ga TTG in the Tarim Craton in northwestern China (Ge et al. 2018). According to Ge et al. (2018), the origin of high-pressure TTG can be interpreted as a result of partial melting of a subducted proto-arc during arc accretion. Further investigation of the geochemistry of 


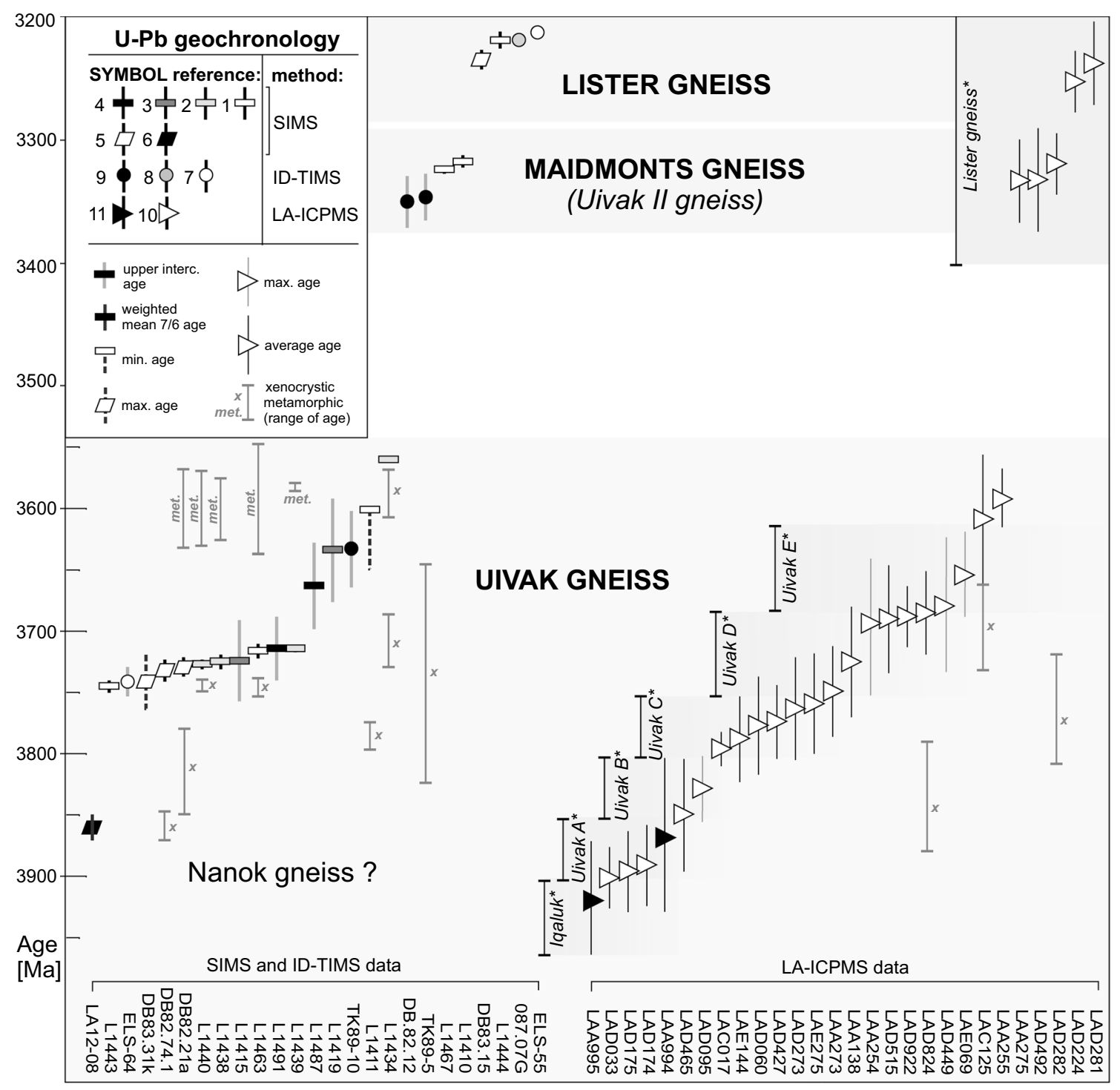

Fig. 8 Summary of available $\mathrm{U}-\mathrm{Pb}$ zircon age determinations of gneisses from the Saglek Block in Labrador. Data sources: 1-this study; 2-Sałacińska et al. (2018); 3-Kusiak et al. (2018); 4Dunkley et al. (submitted); 5-Schiøtte et al. (1989a); 6-Vezinet

the Saglek Block will be needed to determine the relative veracity of these petrogenetic scenarios.

\section{Reassignment of units}

Considering the ambiguity in the definition of Uivak II gneiss in the available literature, together with our new results presented here, we propose a re-definition of gneissic nomenclature in the Saglek Block as follows.

Uivak Gneiss was previously called "early grey gneisses" (Bridgwater et al. 1975), "Uivak I gneiss" (Bridgwater and Collerson 1976) and "Uivak A-E gneisses" (Komiya et al. et al. (2018); 7-Wasteneys et al. (1996); 8-Schiøtte et al. (1990); 9-Krogh and Kamo (2006); 10-Komiya et al. (2017); 11-Shimojo et al. (2016). Italics—previously proposed name of units; *classification of units proposed by Komiya et al. (2017)

2017) and is a diverse group of Eoarchean TTG gneisses whose protoliths formed in a series of unrelated magmatic events (Fig. 8), with some evidence of crustal reworking, and affected by at least one major period of deformation and metamorphism prior to intrusion of what has been referred to in the literature as the 'Uivak II gneiss'. This early Archean tectonothermal event occurred at ca. $3.6 \mathrm{Ga}$ (Sałacińska et al. 2018 and references therein).

Maidmonts Gneiss is a new term introduced here for what has previously been called "Uivak II augen gneiss" (Bridgwater and Collerson 1976), with the type area located on the western side of Maidmonts Island. It is a ca. $3.3 \mathrm{Ga}$ crustally-generated granitoid that post-dates both formation 
of the Eoarchean TTG gneisses and the ca. 3.6 Ga tectonothermal event (Fig. 8). It includes porphyritic and non-porphyritic granitoids intruded prior to Neoarchean metamorphism and deformation.

Lister Gneiss is as the previous definition (Schiøtte et al. 1989a) and therefore remains unchanged. This is a ca. $3.2 \mathrm{Ga}$ granitoid gneiss (Fig. 8), occurring within Eoarchean Uivak gneiss in the amphibolite facies domain to the east of the Handy Fault. It is commonly indistinguishable in the field from Uivak gneiss due to lack of intrusive relationships between these two units. The type locality is Lister Island. The 3.2-3.4 Ga gneisses grouped together by Komiya et al. (2017) as Lister gneiss likely include samples from both the Lister gneiss and the Maidmonts gneiss and should be viewed with caution.

The new data in this study, when combined with those from previous SIMS and ID-TIMS based studies, indicate a significant episode of granitoid magmatism between 3.75 and $3.70 \mathrm{Ga}$, with further magmatism occurring before highgrade metamorphism at ca. $3.6 \mathrm{Ga}$ (Fig. 8). Earlier magmatic activity in the Saglek Block is also indicated by zircon inheritance, with ages up to $3.9 \mathrm{Ga}$. Together, these results and interpretation differ from the distribution of LA-ICP-MS ages obtained by Shimojo et al. (2016) and Komiya et al. (2017), who suggested a prolonged production of granitic magmas between ca. 3.95 and $3.6 \mathrm{Ga}$. In support of this distinction, a similar range of granitoid ages has been identified in the Færingehavn Terrane of West Greenland (as summarized in Sałacińska et al. 2018), which was conjugate to the Saglek Block prior to the opening of the Labrador Sea. Komiya et al. (2017) subdivided their granitoid ages into six generations of gneisses (Iqaluk and Uivak A-E). However, these divisions bear little relation to the distribution of ages, and the lack of precision in the geochronological data may obscure a more episodic magmatic history. Pre-3.8 Ga ages, such as those obtained by Shimojo et at. (2016), Komiya et al. (2017) and Vezinet et al. (2018) clearly demonstrate the presence of older crustal components in the TTG gneisses of the Saglek Block, as is the case in the Færingehavn Terrane of West Greenland. Further precise geochronology will be required to establish the full extent of this older component.

\section{Conclusions}

Eoarchean Uivak gneisses in the Saglek Block, previously called "Uivak I gneiss", represent different generations of magmatism over an interval between ca. 3.9 and $3.6 \mathrm{Ga}$, with major magmatic events occurring between 3.75 and $3.70 \mathrm{Ga}$, prior to tectono-metamorphic activity at ca. $3.6 \mathrm{Ga}$. These include TTG gneisses with evidence of significant input resulting from crustal reworking, as indicated by zircon inheritance. Our results show that the porphyroclastic gneisses on Maidmonts Island, previously assigned to "Uivak II gneiss", were derived from a granite protolith emplaced at ca. $3.32 \mathrm{Ga}$, after the ca. 3.6 Ga tectono-metamorphic event. Grey granitic gneisses of the same age and composition are found elsewhere in the Saglek area and are considered to be co-genetic. We propose a re-definition of so-called "Uivak II gneiss", naming it "Maidmonts gneiss", after the type locality on Maidmonts Island. The Lister gneiss is a distinct unit from the Maidmonts gneiss, contrary to the view of Komiya et al. (2017), with the tonalitic protolith formed at $3219 \pm 7 \mathrm{Ma} \mathrm{Ga}$, and an unknown relationship to the older gneisses. Consequently, we define the Uivak gneiss to be all TTG rocks generated before the ca. 3.6 Ga tectonothermal event, and no longer requiring further subdivision into Uivak I and Uivak II gneisses.

Acknowledgements This research was conducted thanks to a Grant to MAK by the Polish National Science Centre NCN (UMO 2014/15/B/ ST10/04245), and grants to AS by SYNTHESYS (SE-TAF-6912) in the Swedish Museum of Natural History and an ING PAN internal project for young scientists. We also acknowledge grants to MJW from the Knut and Alice Wallenberg Foundation (2012.0097) and the Swedish Research Council (2012-4370). Fieldwork was carried out with the permission and support of Parks Canada and the Nunatsiavut Government. Special thanks to Darroch Whitaker and Martin Lougheed from Parks Canada and Rodd Laing form the Nunatsiavut Government for support in the field. The NordSIMS facility operates as Swedish/Icelandic infrastructure, of which this is publication \# 580.

OpenAccess This article is distributed under the terms of the Creative Commons Attribution 4.0 International License (http://creativeco mmons.org/licenses/by/4.0/), which permits unrestricted use, distribution, and reproduction in any medium, provided you give appropriate credit to the original author(s) and the source, provide a link to the Creative Commons license, and indicate if changes were made.

\section{References}

Alderton DHM, Pearce JA, Potts PJ (1980) Rare earth element mobility during granite alteration: evidence from southwest England. Earth Planet Sci Lett 49:149-165

Baadsgaard H, Collerson KD, Bridgwater D (1979) The Archaean gneiss complex of northern Labrador. 1. Preliminary $\mathrm{U}-\mathrm{Th}-\mathrm{Pb}$ geochronology. Can J Earth Sci 16(4):951-961

Barker F (1979) Trondhjemites: definition, environment and hypothesis of origin. In: Barker F (ed) Trondhjemites, dacites and related rocks. Elsevier, Amsterdam, pp 1-12

Bridgwater D, Collerson KD (1976) The major petrological and geochemical characters of the 3600 m.y. uivak gneisses from labrador. Contrib Mineral Petrol 54:43-59

Bridgwater D, Collerson KD (1977) On the origin of early archaean gneisses: a reply. Contrib Mineral Petrol 62:179-191

Bridgwater D, Schiøtte L (1991) The Archaean gneiss complex of Northern Labrador - a review of current results, ideas and problems. Bull Geol Soc Denmark 39:153-166

Bridgwater D, Watson J, Windley BF (1973) The Archaean craton of the North Atlantic region. Philos Trans Roy Soc London A 273:493-512 
Bridgwater D, Collerson KD, Hurst RW, Jesscau CW (1975) Field characters of the early Precambrian rocks from Saglek, Coast of Labrador, Report of Activities. Department of Energy, Mines and Resources, Geological Survey of Canada, Ottawa, pp 287-296

Chadwick B, Nutman AP (1979) Archaean structural evolution in the northwest Buksefjorden region S.W. Greenland. Precambrian Res 9:199-226

Collerson KD (1983) Ion microprobe zircon geochronology of the Uivak gneisses: implications for the evolution of early terrestrial crust in the North Atlantic Craton. Lunar and Planetary Institute Technical Report, Houston, Textas, pp 28-33

Collerson KD, Bridgwater D (1979) Metamorphic development of early Archaean tonalitic and trondhjemitic gneisses: Saglek area, Labrador. In: Barker F (ed) Trondhjemites, dacites, and related rocks. Elsevier, Amsterdam, pp 205-271

Collerson KD, Kerr A, Vocke RD, Hanson GN (1982) Reworking of sialic crust as represented in late Archaean-age gneisses, northern Labrador. Geology 10:202-208

Condie KC (2005) TTGs and adakites: are they both slab melts? Lithos 80:33-44

Condie KC, Sinha AK (1996) Rare earth and other trace element mobility during mylonitization: a comparison of the Brevard and Hope Valley shear zones in the Appalachian Mountains. USAJ Metamorph Geol 14:213-226

Connelly JN, Ryan B (1996) Late Archean evolution of the Nain Province, Nain, Labrador: imprint of a collision. Can J Earth Sci 33:1325-1342

Crowley JL (2003) U-Pb geochronology of 3810-3630 Ma granitoid rocks south of the Isua greenstone belt, southern West Greenland. Precambrian Res 126:235-257

Drummond MS, Defant MJ (1990) A model for trondhjemitetonalite-dacite genesis and crustal growth via slab melting: Archaean to modern comparisons. J Geophys Res 95:21503-21521

Dunkley DJ, Kusiak MA, Wilde SA, Whitehouse MJ, Sałacińska A, Kielman R, Konečný P (submitted) Two Neoarchean orogenies on the western edge of the North Atlantic Craton, as revealed by SIMS dating of the Saglek Block, Nain Province, Labrador. $\mathrm{J}$ Geol Soc Lond

Fedo CM, Myers J, Appel PWU (2001) Depositional setting and paleogeographic implications of Earth's oldest supracrustal rocks, the $>3.7 \mathrm{Ga}$ Isua Greenstone belt, West Greenland. Sed Geol 141-142:61-77

Foley S, Tiepolo M, Vanucci R (2002) Growth of early continental crust controlled by melting of amphibolite in subduction zones. Nature 417:837-840

Friend CRL, Nutman AP (2005) Complex 3670-3500 Ma orogenic episodes superimposed on juvenile crust accreted between 3850 and $3690 \mathrm{Ma}$, Itsaq Gneiss Complex, Southern West Greenland. J Geol 113(4):375-397

Ge R, Zhu W, Wilde SA, Wu H (2018) Remnants of Eoarchean continental crust derived from a subducted proto-arc. Sci Adv 4:eaao3159

Greene BA (1974) Outline of geology of Labrador. Geosci Can $1(3): 36-40$

Griffin WL, McGregor VR, Nutman AP, Taylor PN, Bridgwater D (1980) Early Archaean granulite-facies metamorphism south of Ameralik, West Greenland. Earth Planet Sci Lett 50:59-74

Hoffmann JE, Münker C, Næraa T, Rosing MT, Herwartz D, GarbeSchönberg D, Svahnberg H (2011) Mechanisms of Archean crust formation inferred from high-precision HFSE systematic in TTGs. Geochim Cosmochim Acta 75:4157-4178

Hoffmann JE. Nagel TJ, Münker C, Næraa T, Rosing MT (2014) Constraining the process of Eoarchean TTG formation in the Itsaq Gneiss Complex, southern West Greenland. Earth Planet Sci Lett 388:374-386
Hölttä P, Balagansky V, Garde AA, Mertanen S, Peltonen P, Slabunov A, Sorjonen-Ward P, Whitehouse M (2008) Archean of greenland and fennoscandia. Episodes 31(1):13-19

Hurst RW, Bridgwater D, Collerson KD, Wetherill GW (1975) 3600 m.y. $\mathrm{Rb}-\mathrm{Sr}$ ages from very early Archaean gneisses from Saglek Bay, Labrador. Earth Planet Sci Lett 27:393-403

Irvine TN, Baragar WRA (1971) A guide to the chemical classification of the common volcanic rocks. Can J Earth Sci 8:523-548

Jahn B, Glikson AY, Peucat JJ, Hickman AH (1981) REE geochemistry and isotopic data of Archaean silicic volcanics and granitoids from the Pilbara block, western Australia: implications for early crustal evolution. Geochim Cosmochim Acta 45:1633-1652

Janoušek V, Moyen JF, Martin H, Erban V, Farrow C (2016) Geochemical modelling of igneous processes-principles and recipes in R language. Springer Geochemistry, New York

Jeon $\mathrm{H}$, Whitehouse MJ (2015) A critical evaluation of U-Pb calibration schemes used in SIMS zircon geochronology. Geostand Geoanal Res 39:443-452

Kamber BS, Ewart A, Collerson KD, Bruce M, McDonald GD (2002) Fluid-mobile trace element constraints on the role of slab melting and implications for Archaean crustal growth models. Contrib Mineral Petrol 144:38-56

Komiya T, Yamamoto S, Aoki S, Sawaki Y, Ishikawa A, Tashiro T, Koshida K, Shimojo M, Aoki K, Collerson KD (2015) Geology of the Eoarchean,>3.95 Ga, Nulliak supracrustal rocks in the Saglek Block, northern Labrador, Canada: the oldest geological evidence for plate tectonics. Tectonophysics 662:40-66

Komiya T, Yamamoto S, Aoki S, Koshida K, Shimojo M, Sawaki Y, Aoki K, Sakata S, Yokoyama TD, Maki K, Ishikawa A, Hirata $\mathrm{T}$, Collerson KD (2017) A prolonged granitoid formation in Saglek Block, Labrador: Zonal growth and crustal reworking of continental crust in the Eoarchean. Geosci Front 8:355-385

Krogh TE, Kamo SL (2006) Precise U-Pb zircon ID-TIMS ages provide an alternative interpretation to early ion microprobe ages and new insights into Archean crustal processes, northern Labrador. In: Reimold WU, Gibson RL (eds) Processes on the early earth, vol 405. Geological Society of America, pp 91-103

Kusiak MA, Dunkley DJ, Whitehouse MJ, Wilde SA, Sałacińska A, Konečný P, Szopa K, Gawęda A, Chew D (2018) Peak to post-peak thermal history of the Saglek Block of Labrador: a multiphase and multi-instrumental approach to geochronology. Chem Geol 484:210-223

Ludwig KR (2012) Isoplot 3.75: a geochronological toolkit for microsoft excel. Berkeley Geochronology Center Special Publication 5

Martin H (1987) Petrogenesis of Archaean trondhjemites, tonalites and granodiorites from eastern Finland; major and trace element geochemistry. J Petrol 28:921-953

Martin H (1993) The mechanisms of petrogenesis of the Archean continental crust-comparison with modern processes. Lithos 30:373-388

Martin H, Smithies RH, Rapp RP, Moyen JF, Champion DC (2005) An overview of adakite, tonalite-trondhjemite-granodiorite (TTG) and sanukitoid: relationships and some implications for crustal evolution. Lithos 79:1-24

McDonough W, Sun SS (1995) The composition of the Earth. Chem Geol 67(5):1050-1056

McGregor VR (1973) The early Precambrian gneisses of the Godthåb district, West Greenland. Philos Trans R Soc A A273:343-358

McGregor VR, Mason B (1977) Petrogenesis and geochemistry of metabasaltic and metasedimentary enclaves in the Ami1tsoq gneisses, West Greenland. Am Mineral 62:887-904

Middlemost E (1994) Naming materials in the magma/igneous rock system. Earth Sci Rev 37:215-224 
Moyen JF (2011) The composite Archaean grey gneisses: petrological significance, and evidence for a non-unique tectonic setting for Archaean crustal growth. Lithos 123:21-36

Moyen JF, Stevens G (2006) Experimental constraints on TTG petrogenesis: implications for Archean geodynamics. In: Benn K, Mareschal JC, Condie KC (eds) Archean geodynamics and environments, Geophysical monograph series. American Geophysical Union, Washington DC, pp 149-175

Næraa T, Scherstén A, Kemp AIS, Rosing MT, Hoffmann JE, Kokfelt TF, Whitehouse MJ (2012) Hafnium isotope evidence for a transition in the dynamics of continental growth $3.2 \mathrm{Gyr}$ ago. Nature 485:627-631

Nutman AP, Bridgwater D, Fryer B (1984) The iron rich suite from the Amitsoq gneisses of southern West Greenland: Early Archaean plutonic rocks of mixed crustal and mantle origin. Contrib Mineral Petrol 87:24-34

Nutman AP, McGregor VR, Friend CRL, Bennett VC, Kinny PD (1996) The Itsaq Gneiss Complex of southern west Greenland, the world's most extensive record of early crustal evolution (3900$3600 \mathrm{Ma}$ ). Precambrian Res 78:1-39

Nutman AP, Bennett VC, Friend CRL, Norman MD (1999) Meta-igneous (non-gneissic) tonalites and quartz-diorites from an extensive ca. 3800 Ma terrain south of the Isua supracrustal belt, southern West Greenland: constraints on early crust formation. Contrib Mineral Petrol 137:364-388

Nutman AP, Friend CRL, Bennett VC, McGregor VR (2000) The early Archaean Itsaq Gneiss Complex of southern West Greenland: the importance of field observations in interpreting dates and isotopic data constraining early terrestrial evolution. Geochim Cosmochim Acta 64:3035-3060

Nutman AP, Friend CRL, Bennett VC (2002) Evidence for 3650-3600 Ma assembly of the northern end of the Itsaq Gneiss Complex, Greenland: implication for early Archean tectonics. Tectonics 21(5):15-28

Nutman AP, Friend CRL, Barker SS, McGregor VR (2004a) Inventory and assessment of Palaeoarchaean gneiss terrains and detrital zircons in southern West Greenland. Precambrian Res 135:281-314

Nutman AP, Friend CRL, Bennett VC, McGregor VR (2004b) Dating of the Ameralik dykes of the Nuuk district, Greenland: multiple intrusion events starting from ca. $3510 \mathrm{Ma}$. J Geol Soc Lond 161:421-430

Nutman AP, Friend CRL, Horie K, Hidaka H (2007) The Itsaq Gneiss Complex of Southern West Greeland and the construction of Eoarchaean Crust at Convergent Plate Boundaries. In: Kranendonk M, Smithies R, Bennet VC (eds) Earth's oldest rocks. Elsevier BV, Amsterdam, pp 187-218

Nutman AP, Bennett VC, Friend CRL, Hidaka H, Yi K, Lee SR, Kamiichi T (2013) The Itsaq Gneiss Complex of Greenland: Episodic 3900 to $3660 \mathrm{Ma}$ juvenile crust formation and recycling in the 3660 to 3600 Ma Isukasian orogeny: Am. J Sci 313(9):877-911

O'Connor JT (1965) A classification for quartz-rich igneous rocks based on feldspar ratios. In: US Geological Survey Professional Paper B525. USGS, pp 79-84

Polat A, Hofmann AW (2003) Alteration and geochemical patterns in the 3.7-3.8 Ga Isua greenstone belt, West Greenland. Precambrian Res 126:197-218

Polat A, Frei R, Scherstén A, Appel PWU (2010) New age (ca. 2970 $\mathrm{Ma}$ ), mantle source composition and geodynamic constraints on the Archean Fiskenæsset anorthosite complex, SW Greenland. Chem Geol 277:1-20

Rapp RP, Watson EB, Miller CF (1991) Partial melting of amphibolite/ eclogite and the origin of Archaean trondhjemites and tonalites. Precambrian Res 51:1-25

Rapp RP, Shimizu N, Norman MD (2003) Growth of early continental crust by partial melting of eclogite. Nature 425:605-609
Ryan B, Martineau Y (2012) Revised and coloured edition of 1992 map showing the Geology of the 813 Saglek Fiord - Hebron Fiord area, Labrador (NTS 14L/2,3,6,7). Scale: 1:100 000, Government of 814 Newfoundland and Labrador, Department of Natural Resources, Geological Survey, Map 2012-2015, 815 Open File 2014L/0091 (Update of map originally released as Newfoundland Department of Mines and 816 Energy, Geological Survey Branch, Map 2092-2018B and Geological Survey of Canada, Open File $8172466)$

Sałacińska A, Kusiak MA, Whitehouse MJ, Dunkley DJ, Wilde SA, Kielman R (2018) Complexity of the early Archean Uivak Gneiss: Insights from Tigigagkyuk Inlet, Saglek Block, Labrador, Canada and possible correlations with south West Greenland. Precambrian Res 315:103-119

Schiøtte L, Compston W, Bridgwater D (1989a) Ion-probe U-Th-Pb zircon dating of polymetamorphic orthogneisses from northern Labrador, Canada. Can J Earth Sci 26:1533-1556

Schiøtte L, Compston W, Bridgwater D (1989b) U-Th-Pb ages of single zircons in Archean supracrustals from Labrador, Canada. Can J Earth Sci 26:2636-2644

Schiøtte L, Noble S, Bridgwater D (1990) U-Pb mineral ages from northern Labrador: possible evidence for interlayering of Early and Middle Archean tectonic slices. Geosci Can 17(4):227-231

Shand SJ (1943) Eruptive rocks. Their genesis, composition, classification, and their relation to ore-deposits with a chapter on meteorite. Wiley, New York

Shimojo M, Yamamoto S, Sakata S, Yokoyama TD, Maki K, Sawaki Y, Ishikawa A, Aoki K, Aoki S, Koshida K, Tashiro T, Hirata T, Collerson KD, Komiya T (2016) Occurrence and geochronology of the Eoarchean, 3.9 Ga, Iqaluk Gneiss in the Saglek Block, northern Labrador, Canada: Evidence for the oldest supracrustal rocks in the world. Precambrian Res 278:218-243

Stacey JS, Kramers JD (1975) Approximation of terrestrial lead isotope evolution by a two-stage model. Earth Planet Sci Lett 26:207-221

Tashiro T, Ishida A, Hori M, Igisu M, Koike M, Méjean P, Takahata N, Sano Y, Komiya T (2017) Early trace of life from 3.95 Ga sedimentary rocks in Labrador, Canada. Nature 549:516-518

Taylor FC (1971) A revision of Precambrian structural provinces in northeastern Quebec and northern Labrador. Can J Earth Sci 8(5):579-584

Vezinet A, Pearson DG, Thomassot E, Stern RA, Sarkar C, Luo Y, Fisher CM (2018) Hydrothermally-altered mafic crust as source for early Earth TTG: $\mathrm{Pb} / \mathrm{Hf} / \mathrm{O}$ isotope and trace element evidence in zircon from TTG of the Eoarchean Saglek Block, N. Labrador. Earth Planet Sci Lett 503:95-107

Wanless RK, Bridgwater D, Collerson KD (1979) Zircon age measurements for Uivak II gneisses from the Saglek area. Labrador Can J Earth Sci 16:962-965

Ward CD, McArthur JM, Walsh JN (1992) Rare earth element behaviour during evolution and alteration of the Dartmoor Granite, SW England. J Petrol 33:785-815

Wardle RJ, Gower CF, Ryan B, Nunn GA, James DT, Kerr A (1997) Geological Map of Labrador: 1:1 million scale. Government of Newfoundland and Labrador, Department of Mines and Energy, Geological Survey, Map 97-07

Wasteneys HA, Wardle RJ, Krogh TE (1996) Extrapolation of tectonic boundaries across the Labrador shelf: $\mathrm{U}-\mathrm{Pb}$ geochronology of well samples: Can. J Earth Sci 33:1308-1324

Whitehouse MJ, Dunkley DJ, Kusiak MA, Wilde SA (2019) On the true antiquity of Eoarchean chemofossils - assessing the claim for Earth's oldest biogenic graphite in the Saglek Block of Labrador. Precambrian Res 323:70-81

Whitehouse MJ, Kamber BS (2005) Assigning dates to thin gneissic veins in high-grade metamorphic terranes: a cautionary tale from Akilia, southwest Greenland. J Petrol 46:291-318 
Whitehouse MJ, Kamber BS, Moorbath S (1999) Age significance of $\mathrm{U}-\mathrm{Th}-\mathrm{Pb}$ zircon data from early Archaean rocks of west Greenland-a reassessment based on combined ion-microprobe and imaging studies. Chem Geol 160:201-224

Wiedenbeck M, Alle P, Corfu F, Griffin WL, Meier M, Oberli F, Vonquadt A, Roddick JC, Speigel W (1995) 3 natural zircon standards for $\mathrm{U}-\mathrm{Th}-\mathrm{Pb}, \mathrm{Lu}-\mathrm{Hf}$, trace-element and ree analyses. Geostand Newslett 19:1-23

Zeck HP, Whitehouse MJ (1999) Hercynian, Pan-African, Proterozoic and Archean ion-microprobe zircon ages for a Betic-Rif core complex, Alpine belt, W Mediterranean - consequences for its $\mathrm{P}-\mathrm{T}-\mathrm{t}$ path. Contrib Mineral Petr 134:134-149 